\title{
Digital Health Interventions in Palliative Care: A Systematic Meta-Review and Evidence Synthesis
}

\author{
*Anne M. Finucane ${ }^{1}$ \\ Marie Curie Hospice Edinburgh, Scotland, United Kingdom \\ Primary Palliative Care Research Group, Usher Institute of Population Health Sciences and \\ Informatics, University of Edinburgh, Scotland, United Kingdom

\section{Hannah O'Donnell ${ }^{1}$} \\ eHealth Research Group, Usher Institute of Population Health Sciences and Informatics, University \\ of Edinburgh, Scotland, United Kingdom

\section{Jean Lugton} \\ Marie Curie Hospice Edinburgh, Scotland, United Kingdom

\section{Connie Swenson} \\ Marie Curie Hospice Edinburgh, Scotland, United Kingdom

\section{Claudia Pagliari} \\ eHealth Research Group, Usher Institute of Population Health Sciences and Informatics, University \\ of Edinburgh, Scotland, United Kingdom
}

${ }^{1}$ Anne M Finucane and Hannah O’Donnell are joint first authors

\section{Corresponding author:}

*Anne Finucane, Marie Curie Hospice Edinburgh, 45 Frogston Road West, Edinburgh, EH10 7DR, Scotland, United Kingdom.

Email: anne.finucane@mariecurie.org.uk

\section{Wordcount: 4961}




\begin{abstract}
Digital health interventions (DHIs) have the potential to improve the accessibility and effectiveness of palliative care but heterogeneity amongst existing systematic reviews presents a challenge for evidence synthesis. This rigorous meta-review applied a structured search of 10 databases from 2006 to 2020, revealing 21 relevant systematic reviews, encompassing 332 unique publications. Most reviews were moderate quality. Interventions delivered via videoconferencing (17\%), electronic healthcare records $(16 \%)$ and phone $(13 \%)$ were most frequently described. DHIs were typically used in palliative care for education (20\%), symptom management (15\%), decisionmaking support (13\%), information provision or management (13\%), and communication (9\%). Positive impacts were reported on education, decision-making, information-sharing, communication, and costs. Impacts on symptom management were either positive or showed no harmful effects. However often DHIs were described but not evaluated. Responsive pragmatic research designs are now needed to guide further evaluation, implementation and to inform future service innovation.
\end{abstract}


The diagnosis of a life-limiting illness, along with its management during periods of wellness, illness, remission, decline and end-of-life can be stressful for patients, caregivers, and healthcare professionals. Palliative care offers a holistic set of approaches for ameliorating the physical, psychological, social and spiritual burdens patients and their families face. ${ }^{1,2}$ Improving access to, and increasing the quality of palliative care delivered is a healthcare priority in many countries..$^{3,4}$ Digital health interventions (DHIs) could have an essential role to play in achieving these aims.

Digital health, or eHealth, is a broad term used to refer to the application of information and communication technologies (ICTs) and networks for the management, delivery and optimisation of patient care and health services, and for supporting patients themselves. It encompasses a range of related concepts such as telemedicine and telehealth, mobile $(\mathrm{m})$ Health, health informatics, and wearable devices. ${ }^{5,6}$ The adoption of digital health technologies is rapidly changing how healthcare is provided. Electronic health records (EHRs) and decision support tools are part of routine healthcare practice in many countries. Mobile phones, apps, wearables and social media are in widespread use, and innovations such as augmented reality, virtual assistants and artificial intelligence are finding new uses in clinical management and patient self-care. These approaches are reshaping healthcare as they become more affordable and widespread. ${ }^{7}$

Palliative care is one area where these technologies are increasingly being deployed. ${ }^{8}$ Research to establish the feasibility of using videoconferencing in palliative care was first reported nearly 20 years ago. ${ }^{9}$ In healthcare organisations, pathways and preferences for palliative care are being steadily integrated into EHRs. ${ }^{10}$ In parallel, mobile applications and online social networks for supporting patients' physical, cognitive and emotional needs are becoming popular, both supplied by healthcare providers ${ }^{11}$ and driven by patients and carers themselves. ${ }^{12}$ More recently, predictive 
analytics and artificial intelligence are being used to adapt clinical interventions to stages of terminal illness. ${ }^{13}$

Reflecting this activity, there has been a significant rise in the number of systematic reviews focused on DHIs and palliative care over the past 15 years. ${ }^{14-18}$ Despite their general support for these approaches, the clinical scope and quality of existing reviews varies widely, making it difficult to evaluate their implications for the field as a whole. Given the growing demand for palliative care services worldwide ${ }^{19}$ and the increasing penetration of DHIs in healthcare, the time is right for a comprehensive synthesis and appraisal of this evidence base. We employed the metareview method to capture, appraise and synthesise the evidence represented in the systematic review literature on DHIs in palliative care. Our objectives were:

1. To identify the range of palliative DHIs described in existing systematic reviews.

2. To describe the quality of existing systematic review evidence.

3. To synthesize evidence on the role and the effects of DHIs in palliative care.

4. To identify evidence gaps and make recommendations for future research.

\section{RESULTS}

\section{Search results}

The database searches returned a total of 5092 titles and abstracts, of which 55 potentially relevant papers were subjected to full-text review and 21 were eligible for inclusion (Figure 1). The main reason for excluding articles at full text review was that they were not focused on palliative care 
medRxiv preprint doi: https://doi.org/10.1101/2020.09.16.20195834; this version posted September 18, 2020. The copyright holder for this preprint (which was not certified by peer review) is the author/funder, who has granted medRxiv a license to display the preprint in perpetuity.

It is made available under a CC-BY-NC-ND 4.0 International license .

(13 studies) or DHIs (7 studies); not systematic reviews (4 studies); reviews of apps as opposed to research (3 studies); did not report on effects of DHIs or provide detail on included reviews (4 studies) or other reasons (3 studies). During the search process we identified one meta-review of telemedicine in palliative care published in $2016 .{ }^{20}$ This meta-review identified a total of 6 systematic reviews published between 2007 and 2012, all of which were included amongst the 21 eligible reviews in this meta-review. 
medRxiv preprint doi: https://doi.org/10.1101/2020.09.16.20195834; this version posted September 18, 2020. The copyright holder for this preprint (which was not certified by peer review) is the author/funder, who has granted medRxiv a license to display the preprint in perpetuity.

It is made available under a CC-BY-NC-ND 4.0 International license .

Figure 1: Prisma diagram

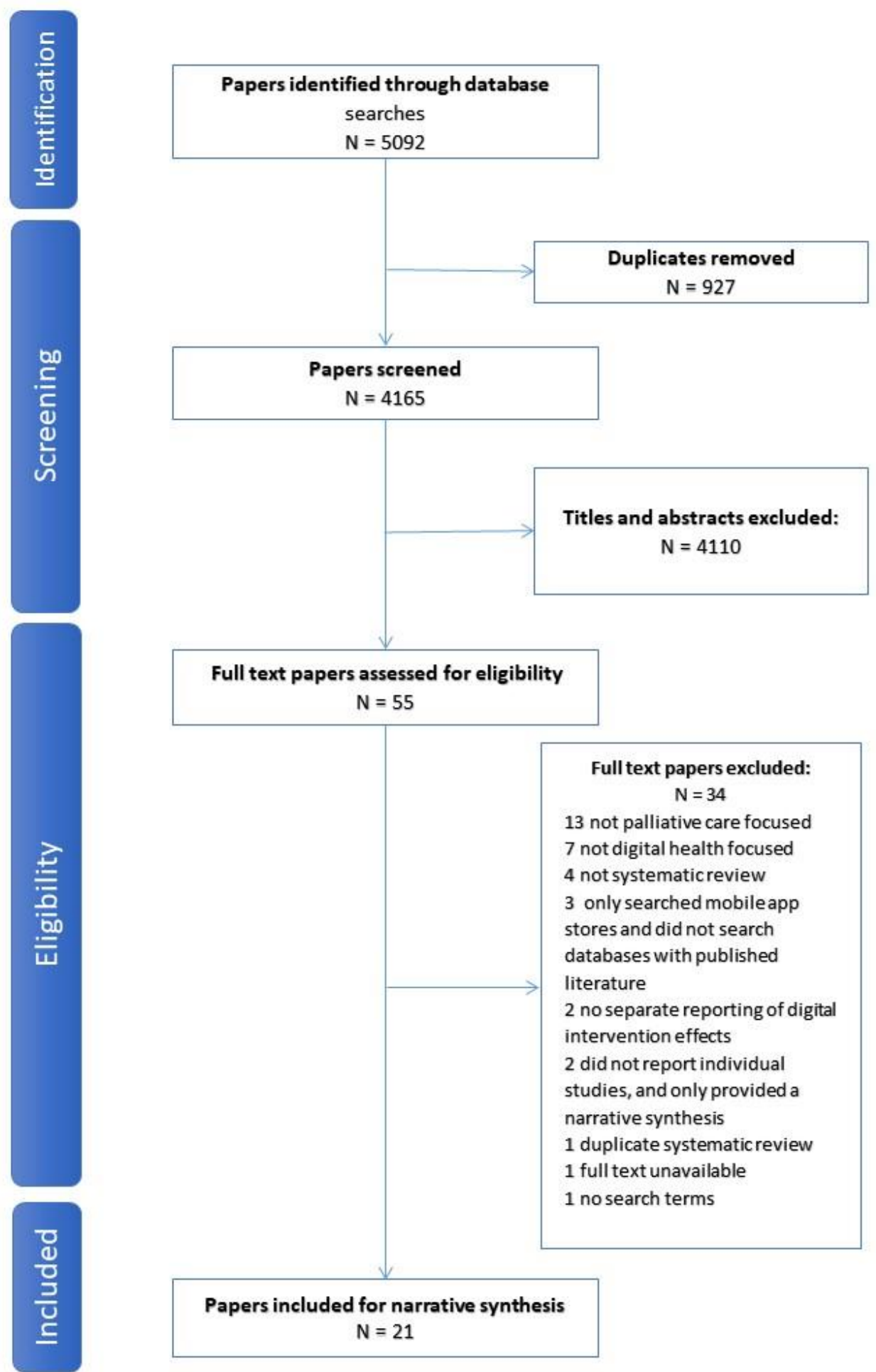




\section{Description of the included studies}

\section{Characteristics of the included reviews}

Characteristics of the 21 included reviews are shown in Table 1 (See Appendix). Most included a range of study populations - patients, family members, caregivers, and health professionals. Three reviews focused on cancer, ${ }^{21-23}$ others did not limit their inclusion criteria a specific disease. The reviews were carried out by research teams based in the following countries: USA (9), ${ }^{17,24-31}$ UK (6), ${ }^{16,23,32-35}$ Australia (2), ${ }^{14,36}$ Canada (1) ${ }^{22}$ Chile (1), ${ }^{15}$ Denmark (1) ${ }^{37}$ and Brazil $(1)^{38}$.

The number of studies related to DHIs and palliative care in each review ranged from $5^{33}$ to $39^{37}$ Taken together the reviews summarised evidence from 332 unique publications, including four systematic reviews. The 21 reviews were published between 2007 and 2019 and included a total of 41 RCTs. None of the reviews pooled data to perform meta-analyses due to the heterogeneity of included studies.

Ten systematic reviews covered broad areas such as telehealth, ${ }^{14,16,24,30,31,34}$ telehospice, ${ }^{17}$ ehealth $^{15}$ information and communication technologies. ${ }^{23,25}$ Eleven reviews had a more specific focus: EHRs,${ }^{27,28,35,36}$ internet, ${ }^{26,38}$ weblogs,${ }^{39}$ mhealth, ${ }^{33}$ telephone, ${ }^{22}$ video conferencing, ${ }^{37}$ and simulators. $^{29}$

Types of DHIs described in palliative care reviews

We classified the types of DHIs described in 328 publications included in the 21 reviews (Table 2). The most featured DHIs involved videoconferencing or videophone $(\mathrm{n}=56,17 \%)$, EHRs $(\mathrm{n}=51$, $16 \%)$ and telephone or mobile phone $(\mathrm{n}=41,13 \%)$. Online interventions, including educational websites and online courses, were described in 31 publications (9\%). Only six publications were 
medRxiv preprint doi: https://doi.org/10.1101/2020.09.16.20195834; this version posted September 18, 2020. The copyright holder for this preprint (which was not certified by peer review) is the author/funder, who has granted medRxiv a license to display the preprint in perpetuity.

It is made available under a CC-BY-NC-ND 4.0 International license .

focused on social media (2\%), e.g. interactive online blogs. We found a relatively large proportion of studies describing mixed or unspecified DHIs $(n=50,15 \%)$. Mixed DHIs were delivered using a choice of DHIs, or using a DHI with multiple components (e.g. telephone call with follow-up video-consultation). Unspecified studies included general surveys or qualitative studies examining the use of DHIs in general. Studies describing and evaluating EHRs increased over the review period, with more publications on EHRs compared with any other DHI each year since 2016.

Table 2. Types of DHIs reported in publications included in 21 reviews $(n=328)$

\begin{tabular}{|l|c|c|}
\hline Type of Digital Health Intervention & No. of publications & \% of publications \\
\hline Videoconferencing/videophone & 56 & $17 \%$ \\
\hline Electronic health records & 51 & $16 \%$ \\
\hline Phone/mobile phone & 41 & $13 \%$ \\
\hline Online & 31 & $9 \%$ \\
\hline Video & 27 & $8 \%$ \\
\hline Computer & 20 & $6 \%$ \\
\hline PDA / tablet/smartphone & 16 & $5 \%$ \\
\hline High-fidelity Simulator & 16 & $5 \%$ \\
\hline Other (e.g. digital pens) & 7 & $2 \%$ \\
\hline Social media & 6 & $2 \%$ \\
\hline Telemonitoring & 5 & $2 \%$ \\
\hline Text messaging & 2 & $1 \%$ \\
\hline Mixed/unspecified & 50 & $15 \%$ \\
\hline TOTAL & $\mathbf{3 2 8}$ & $\mathbf{1 0 0} \%$ \\
\hline
\end{tabular}


medRxiv preprint doi: https://doi.org/10.1101/2020.09.16.20195834; this version posted September 18, 2020. The copyright holder for this preprint (which was not certified by peer review) is the author/funder, who has granted medRxiv a license to display the preprint in perpetuity.

It is made available under a CC-BY-NC-ND 4.0 International license .

Main purpose of DHIs described in palliative care reviews

DHIs were used for a range of purposes in palliative care (Table 3). A fifth of publications described DHIs for educational purposes $(n=64)$ most frequently involving online learning, simulators and videoconferencing. Symptom management was the main aim of DHIs outlined in $15 \%$ of publications, and all types of DHI were used for this purpose. Decision-making support for patients and professionals was the main purpose of DHIs described in $13 \%$ of publications - video aids and EHRs were often used for this purpose. Information provision or management, often using EHRs, was the main aim of DHIs in $13 \%$ of publications. Communication was the main aim of DHIs in $9 \%$ of publications, with videoconferencing most often used. Overall, $15 \%$ of publications described DHIs for mixed or unspecified purposes. Mixed purposes could include information support and decision-making; or communication and information-sharing. Unspecified purposes had no specific focus.

Table 3. Main purpose of DHIs reported in publications included in 21 reviews $(n=328)$

\begin{tabular}{|l|c|c|}
\hline Purpose of Digital Health Intervention & No. of publications & \% of publications \\
\hline Education & 64 & $20 \%$ \\
\hline Symptom management & 49 & $15 \%$ \\
\hline Information provision or management & 44 & $13 \%$ \\
\hline Decision making support & 42 & $13 \%$ \\
\hline Communication & 29 & $9 \%$ \\
\hline Caregiver support & 14 & $4 \%$ \\
\hline Increase access to palliative care & 11 & $3 \%$ \\
\hline Out of hours care/emergency admissions & 9 & $3 \%$ \\
\hline Clinical follow-up & 9 & $3 \%$ \\
\hline Psychological or psychosocial support & 8 & $2 \%$ \\
\hline Mixed/unspecified & 49 & $15 \%$ \\
\hline TOTAL & $\mathbf{3 2 8}$ & $100 \%$ \\
\hline
\end{tabular}




\section{Quality of evidence}

Quality of the included reviews

The quality of the 21 included reviews varied, with AMSTAR scores ranging from 3 to 10, out of a possible total score of 11 (Supplementary material 1). Most reviews $(n=11)$ were of moderate quality (AMSTAR score between 5 and 8). The median rating of reviews published between 2007 and 2017 was 4, compared to a median rating of 8 for reviews published in 2018 and 2019. All reviews described the characteristics of included studies; most described a comprehensive search strategy (17 of 21) and used independent data extractors (15 of 21). Just over half assessed the quality of evidence and used this information to contextualise the results (11 of 21). Approximately half referred to a protocol or a-priori research objectives (11 of 21). Less than half specified the methods used to combine the results of studies ( 9 of 21). Only a third of reviews ( 7 of 21$)$ searched grey or unpublished literature. None of the reviews considered publication bias, and only one included a list of excluded studies.

Quality of studies within the reviews

Eleven reviews assessed the quality of evidence. ${ }^{14,17,24,25,29-31,34-37}$ Four used the Cochrane risk of bias tool. ${ }^{25,30,31,36}$ One used the Critical Appraisal Skills (CASP) programme tool. ${ }^{14}$ Five reviews used different tools previously described in the literature ${ }^{24,29,34,35,37}$ while one review developed a quality appraisal framework specifically for their review. ${ }^{17}$ Only three reviews described evidence as moderate to high quality. ${ }^{14,17,24}$ Eight reviews reported evidence of low to moderate quality. ${ }^{25,29-}$ 31,34-37 This was due to small sample size, insufficient detail on study design, unclear or high risk of bias, non-blinding of participants and outcomes, and poorly defined comparison groups. 


\section{USE AND EFFECTS OF INTERVENTIONS}

Findings from each review are described in Table 4 (See Appendix) in relation to seven thematic areas: education symptom management, information sharing, decision-making, communication, quality of life and cost-effectiveness.

\section{Education}

Eight reviews identified DHIs for education, of which most focused on describing interventions rather than evaluating their outcomes. ${ }^{15,16,24,25,29,33,34,38}$ Educational interventions were delivered via online learning for professionals, ${ }^{15,25,30,38}$ videoconferencing for professionals, ${ }^{16,34,40}$ videos for professionals, ${ }^{19,25,28}$ online symptom reporting for caregivers, ${ }^{24}$ simulation based learning experiences (SBLEs) for professionals, ${ }^{29}$ and mobile phones/text messaging for education and training of providers and patients. ${ }^{33}$ Two reviews reported that online learning was a feasible alternative to in-person training, though quality of evidence was not assessed. ${ }^{16,38}$ In a review of distance learning for healthcare professionals, Taroca et al. suggested that online case consultations involving active participation of students facilitated knowledge retention. ${ }^{38}$ They also noted the prevalence of mixed educational initiatives (i.e. distance learning and classroom based), with $64 \%$ of studies involving mixed approaches, suggesting a need for classroom activity to consolidate knowledge acquired at a distance. There was no consensus about the most effective learning methods, and most virtual learning environments used a variety of multimedia to support communication and feedback mechanisms. Kidd et al. ${ }^{16}$ suggested that online learning and remote access to guidelines supports dissemination of good practice but also reported that face-to-face teaching methods are preferred when discussing emotional or psychological issues. ${ }^{16}$ Ostherr et 
medRxiv preprint doi: https://doi.org/10.1101/2020.09.16.20195834; this version posted September 18, 2020. The copyright holder for this preprint (which was not certified by peer review) is the author/funder, who has granted medRxiv a license to display the preprint in perpetuity.

It is made available under a CC-BY-NC-ND 4.0 International license .

al. ${ }^{25}$ found strong evidence for benefits of video for educating patients about their illness and helping to determine treatment choices, although the evidence was judged to be at high risk of bias. Smith et al. examined evidence on the use of simulation based learning for end-of-life care conversations, though information on outcomes was absent. ${ }^{29}$

\section{Symptom management}

Thirteen reviews referenced the role of DHIs in monitoring, assessing, and managing physical and psychological symptoms. ${ }^{14-17,22-25,27,30,31,34,37}$ EHRs were used to record symptoms ${ }^{27,34}$ while telephone and videoconferencing were frequently used to monitor, assess and treat symptoms. ${ }^{15,22,23,25,30,37,39}$ Some reviews described positive impacts of DHIs on symptom management, while most reviews identified inconsistent evidence or noted that evaluation of impact in many studies was lacking. In their review of telephone follow-up for patients with advanced cancer, Zhou et al. ${ }^{22}$ concluded that telephone follow-up is a feasible alternative to hospital followup for symptom palliation, and reduces travel burden. Head et al. ${ }^{31}$ reported positive or no impacts of DHIs on patient symptoms (e.g. physical and social functioning), noting that overall evidence was weak. Jess et al. ${ }^{37}$ described positive impacts of videoconferencing on symptom burden, especially in remote settings, though also noted negative impacts in a some studies specifically due to technical challenges which frustrated communication. ${ }^{37}$ Hancock et al. ${ }^{34}$ described home telemonitoring initiatives for patients (e.g. use of the telephone or computer software to record clinical symptoms at home); however most interventions had not been evaluated. Similarly Kidd et al. ${ }^{16}$ described uses of telephone hotlines and electronic questionnaires to inform symptom management, though there was little evaluation. The heterogeneity of outcomes used to assess particular symptoms such as pain was highlighted by Allsop et al. ${ }^{23}$ Bush et al. ${ }^{27}$ described 
evidence linking the documentation of clinical symptoms on an EHR to reduced time in hospital in the last 6 month of life; though this finding was based on just one of the studies included in their review, as it was not directly evaluated in others.

Seven reviews reported effects of DHIs on psychological symptoms - anxiety, depression and distress. ${ }^{14,17,24,30,31,37,39}$ Bradford et al. ${ }^{14}$ described a number of small studies examining videoconferencing interventions for paediatric palliative care, noting reductions in anxiety. Chi et al. ${ }^{24}$ found enhanced psychological health in caregivers (less anxiety, depression, stress, burden, irritation and isolation) associated with DHIs. Similarly Head et al. ${ }^{31}$ identified positive effects of DHIs (telemonitoring and videoconferencing) on patient anxiety, depression and distress. Zheng et al. ${ }^{30}$ reported significant improvements in caregiver anxiety associated with access to videophones. Oliver et al. ${ }^{17}$ identified studies examining the effect of DHIs on anxiety, though studies were not large enough to detect significant differences in outcomes. Jess et al. ${ }^{37}$ found mostly positive impacts of video-conferencing on patient and caregiver anxiety, with the exception of one RCT which found negative impacts. ${ }^{41}$ This RCT compared weekly video-consultations by a palliative care specialist with treatment as usual in home-dwelling patients with advanced cancer. The authors concluded that higher distress in the video-consultation arm may have been due to excess focus on symptoms and suffering, and the provision of pre-scheduled support over 3 months as opposed to when it was actually needed. ${ }^{41}$ Ngwenya et al. ${ }^{39}$ focusing on online blogging, reported that patients experienced a sense of emotional support, social connections and empowerment through writing online blogs. 
medRxiv preprint doi: https://doi.org/10.1101/2020.09.16.20195834; this version posted September 18, 2020. The copyright holder for this

It is made available under a CC-BY-NC-ND 4.0 International license .

\section{Information sharing}

Nine reviews considered the information-sharing value of DHIs, with most describing the value of the information rather than evaluating specific outcomes. ${ }^{15,16,23,26-28,35,36}$ In an early low quality review of internet use, Willis et al. described the positive impacts of the internet as an additional source of information for patients, families and clinicians. ${ }^{26}$ They found that patients and carers used online support groups and chatrooms to exchange information and support about an illness and alternative treatments. Patients and carers developed a connection with others online and appreciated the anonymity associated with online support. Capurro et al. ${ }^{15}$ reported that DHIs were used by clinicians, patients and carers to meet informational needs regarding pain and symptom management and medication use; although the quality of evidence was not assessed. Kidd et al. highlighted the importance of telephone helplines for general practitioners (GPs), nurses, and caregivers for gathering information about managing symptoms and medical equipment. ${ }^{16}$ These telehealth interventions improved the reliability and accuracy of information exchanged. ${ }^{16}$ Allsop et al. ${ }^{23}$ noted that many systems designed to capture information from a patient for use by a healthcare professional, involved relaying symptoms without engaging in active forms of communication.

Four reviews highlighted the information-sharing function of EHRs in palliative care. ${ }^{27,28,35,36}$ All were moderate quality. These reviews concluded that EHRs available across settings and platforms allow patient preferences regarding advance care planning (ACP) to be shared; improving continuity of care and ensuring that patients are treated in line with their wishes. Bush et al. ${ }^{27}$ reported that in low resource settings, the implementation of a standalone EHR system capturing patient demographics and palliative care treatment information was found to significantly improve 
clinical workflow. Leniz et al. ${ }^{35}$ found that those with an EHR shared across settings were more likely to die in their preferred place compared with those who did not have an EHR. However, EHRs were limited in their capacity to capture important qualitative information such as information on anxiety or family distress. ${ }^{27}$ Furthermore, finding the location of relevant ACP information within the EHR was often challenging ${ }^{36}$ though could be improved by ensuring all ACP information is documented in a specific area. ${ }^{27}$ Documentation templates, order sets and prompts, may also improve the quality and incidence of ACP within EHRs. ${ }^{28}$ Having an EHR improves documentation of advance care plans and communication of care planning information; ${ }^{27,28,36}$ but this can come at the cost of increased workload, ${ }^{35}$ challenges identifying which patients should have a shared EHR, ${ }^{36}$ and concerns regarding data-sharing, security and consent. ${ }^{35}$ Huber et al. ${ }^{28}$ suggest that further research focused on developing a consensus definition for ACP documentation and related quality elements in EHRs is needed.

\section{Decision-making}

Four reviews considered the role of DHIs in decision-making by patients ${ }^{25}$ and professionals. ${ }^{27,36,38}$

Ostherr et al. identified 20 studies where video, computer-based multimedia and online materials were used as patient decision-aids to support. ${ }^{25}$ There was strong evidence for the efficacy of video in facilitating ACP decisions, resulting in improvements in completion of advance directives, discussion of end-of-life preferences, and improved patient knowledge and satisfaction. Taroca et al. identified two studies on distance learning courses for decision-making in palliative care, but did not describe the outcomes. ${ }^{38}$ Two reviews considered the role of clinical decision support systems (CDS), including EHRs in facilitating decision-making. ${ }^{27,36}$ Bush et al. ${ }^{27}$ described evidence on the use of such systems to identify patients for a palliative care approach, and to capture ACP directives 
and patient reported outcomes to inform clinical decision-making. Due to heterogeneity of studies, evidence could not be synthesized, but Bush et al. ${ }^{27}$ described positive impacts including a reduced likelihood of ICU admissions and hospital death for those with patient reported outcomes shared via EHR, compared to those without; and earlier identification of patients for ACP discussion. Lemon et al. ${ }^{36}$ found that EHRs can improve documentation of advance directives. Electronic reminders, electronic templates, decision aids and standard locations of advance directives can increase documentation of advance directives. Electronic search systems and identification algorithms located within the EHR can assist with identification of patients who could potentially benefit from a palliative care approach, by flagging those who may have palliative care needs for review by the clinician. Overall, evidence described by Lemon et al. was weak, but points towards promising effects of EHRs for ACP.

\section{Communication}

Ten reviews described the role of DHIs to facilitate communication between patients, professionals and carers using phones, internet, and computer systems. ${ }^{15,23-26,29,31,33,37,39}$ Positive effects included enhanced communication between patients, healthcare professionals and caregivers; ${ }^{15,24,26,37}$ more opportunities to express feelings $;{ }^{39}$ increased connectednesss; ${ }^{15}$ caregiver support ${ }^{17}$ and improved $\mathrm{ACP} .{ }^{25}$ Jess et al. ${ }^{37}$ identified 16 studies relating to the impact of videoconferencing on communication in palliative care. Positive impacts included greater efficiency and access, whereby several participants could be visually present and participate at once; shared decision-making involving the multidisciplinary team, patient and family; and enhanced communication through access to non-verbal as well as verbal responses. Negative impacts could occur where the family 
felt overwhelmed by the involvement of too many participants. Smith et al. ${ }^{29}$ found that simulation based-based learning was frequently used to teach nursing students communication skills in palliative care settings, but due to the lack of standardization and poor evaluation, it was difficult to identify best practices.

\section{Quality of Life}

Seven reviews considered the effects of DHIs on quality of life (QoL). ${ }^{14,17,22,24,30,31,37}$ Most reviews described improvements that were not statistically significant or positive impacts; negative impacts were rarely observed. Zheng et al. found no significant difference in QoL outcomes after telehealth interventions for caregivers. ${ }^{30}$ Head et al. identified one study reporting a positive impact of telephone monitoring on QoL whereas another involving videophones showed no difference. ${ }^{31}$ Similarly, in their review of telehealth for paediatric palliative care, Bradford et $\mathrm{al}^{14}$ found either positive effects on QoL or no significant differences. Zhou et al. reported that telephone follow-ups with patients with advanced cancer reduced the patient burden by eliminating the need to come into hospital, facilitating a better QoL, though quality of evidence was not assessed and insufficient data on included studies was provided. ${ }^{22}$ In a review of telehealth and hospice care, Oliver et al. ${ }^{17}$ reported that studies examining QoL were too small to identify clinically significant differences. In their review of videoconferencing, Jess et al. identified several studies incorporating a QoL measure in their design, but QoL outcomes were not described in their key findings. ${ }^{37}$ In a review of weblogs in palliative care, Ngwenya and Mills ${ }^{39}$ concluded that weblogs improve patient and QoL by empowering patients and giving them a sense of active participation in their treatment, but this was a small scale study with no quality assessment of included studies. In reviews of EHRs, outcomes relating to QoL were rarely assessed. ${ }^{34,35}$ 


\section{Cost effectiveness}

Five reviews considered the financial implications of DHIs, with most reporting positive impacts of DHIs on costs. ${ }^{14-17,37}$ Jess et al. described cost savings associated with video-consultation in palliative care for clinicians, service providers, patients, and caregivers. ${ }^{37}$ In two studies included in their review, video consultations between healthcare professionals and patients resulted in costsavings for the hospital, compared to in-person consultations, and in clinician travel expenses for home visits. Travel cost savings were also noted for patients and carers in rural settings. ${ }^{37}$ In a review of DHIs in hospices, Oliver et al. ${ }^{17}$ identified one telehospice cost analysis study; this study reported reduced costs for telehospice visits versus traditional hospice homecare. Bradford et al. ${ }^{14}$ described cost efficiencies when video-visits were used in place of home visits; and when videoconferencing was used to educate patients about self-care; but cautioned that the costeffectiveness will depend on whether DHIs are used in parallel with, or as a replacement for, traditional approaches. Kidd et al. described DHIs as an efficient alternative for patients and clinicians when time and distance is limiting. ${ }^{16}$ Capurro et al. described cost efficiencies related to reduced hospital visits, but this was based on only one study in their review. ${ }^{15}$ Overall, evidence on cost effectiveness was positive, though interventions and outcomes assessed were heterogeneous, findings were based on a small number of studies, evidence quality was not always assessed and robust economic evaluation not undertaken. 
medRxiv preprint doi: https://doi.org/10.1101/2020.09.16.20195834; this version posted September 18, 2020. The copyright holder for this preprint (which was not certified by peer review) is the author/funder, who has granted medRxiv a license to display the preprint in perpetuity.

It is made available under a CC-BY-NC-ND 4.0 International license .

\section{DISCUSSION}

Main findings: The evidence captured in this meta-review indicates that DHIs in palliative care are being used for education, symptom management, information-sharing, decision-making and communication, with the aim of improving patients' quality of life and the reach and efficiency of services. The methodological quality of the included systematic reviews was mostly moderate, although those published since 2018 tended to be stronger. Primary studies appraised in the reviews were typically of low to moderate quality. Positive impacts of DHIs were reported on education, information-sharing, decision-making and communication in palliative care contexts. Mostly positive effects, or no negative effects, were noted for psychological symptoms and quality of life. For physical symptom management, evidence was inconsistent or absent. No evidence of risks to patient safety was reported. Systematic review authors conclude that DHIs can play a positive, enabling role in palliative care but call for more rigorous evaluation, implementation, and cost-effectiveness studies, with a greater focus on patient perspectives.

Advantages of this study: To date this is the most comprehensive meta-review focused on DHIs in palliative care. Compared to a previous meta-review which encompassed six reviews, ${ }^{20}$ it examined a wider range of databases and identified 21 systematic reviews for critical appraisal and synthesis. This meta-review shows that DHIs are more prevalent in palliative care than previously described; are used for a broader range of purposes, that impacts are generally positive, and overall quality of research evidence is improving.

Limitations of this study: The heterogeneity of reviews aims, methods, and presentation of results created challenges for evidence synthesis. In many reviews DHIs were described but outcomes 
were not described or evaluated in any detail. Although the searches were completed in January 2020, the dates of the primary studies ranged from 1997 to 2018, reflecting the time lag in academic publishing. None of the eligible systematic reviews focused on smartphone applications for palliative care, despite their growing use in this context. ${ }^{42,43}$ Two reviews emerged after our searches had been completed, including a rapid review on video-consultations in palliative care in context of COVID-19, ${ }^{44}$ and a scoping review of patient experiences of telehealth for palliative care at home. ${ }^{45}$ Neither would have been eligible, as they were not systematic reviews, however we suggest that future meta-reviews include all review types.

Methodological gaps: The meta-review findings echo the wider literature on digital health ${ }^{46}$ and palliative care, ${ }^{47}$ which point to the need for more rigorous evaluations, cost-effectiveness analyses, implementation studies and patient centred research. The lack of rigorous cost-effectiveness studies seen in the literature on DHI in palliative care, reflects findings from previous metareviews ${ }^{48,49}$ and systematic reviews ${ }^{50-52}$ in digital health. There is a need for greater clarity on what is being compared in cost-effectiveness studies, and whether the DHI is offered in addition to, or as a replacement to the standard approach. ${ }^{14,25,37}$ Undertaking large, well-powered RCTs on DHIs is challenging, partly because technological developments may outpace the timescale for conventional clinical trials, ${ }^{53}$ and also because, in practice, DHIs are implemented in complex systems as opposed to controlled settings. ${ }^{54}$ More rapid research paradigms, ${ }^{53}$ using responsive pragmatic designs that take account of the context and setting in which the DHI is being evaluated and pay greater attention to the factors that facilitate or hinder adoption, may be more realistic and fruitful in future evaluations of DHIs for palliative care. Interdisciplinary evaluation, combining economic, social and clinical research, is needed to better understand the role of different settings, healthcare 
needs and patient preferences for ensuring the appropriate, safe, acceptable and sustainable use of DHIs in palliative care. Early user involvement (patients, caregivers and staff) will also be key in the design, evaluation and implementation of DHIs in this setting. ${ }^{55}$

Technology evidence gaps: Personal health monitoring devices, such as wrist-worn activity trackers and smartwatches are now widely used and have been evaluated in other digital health contexts. ${ }^{56}$ The absence of evidence about the use of these may reflect the fact that most studies of trackers are taking place in the context of chronic disease management. Nevertheless, it suggests a need for further research in palliative care, particularly for patients managing at home, for whom wearables and ambient computing (e.g. smart homes) are likely to be increasingly useful. The included systematic reviews did not include studies on the use of smartphone apps. Descriptive reviews on the potential that such apps may have in palliative care are emerging and further research is warranted. ${ }^{42,43}$ Studies using machine learning and artificial intelligence for risk detection and prediction, or for delivering personalised support based on data from individual patients, were also not represented amongst the included reviews, despite progress in AI- enabled healthcare delivery. ${ }^{57}$ Research exploring the use of machine learning using EHRs to predict mortality, and identify patients who would benefit from palliative care shows promise; future reviews need to consider this emerging evidence. ${ }^{58}$ Studies involving robots or chatbots were not identified despite their potential application in palliative care. ${ }^{59}$ Evidence on these types of DHIs in palliative care is needed, to understand their benefits and risks. 
Stakeholder evidence gaps: The WHO has developed a classification framework for DHIs which provides a shared vocabulary for all stakeholders, including researchers, when evaluating effectiveness and identifying gaps in the implementation of DHIs across healthcare settings. ${ }^{60}$ The WHO organizes DHIs into overarching categories by user group: clients (e.g. patients or carers), healthcare providers, health system or resource managers and data services. Most of the research evidence on DHIs in palliative care identified in this metareview was focused on DHIs for healthcare providers (e.g. healthcare provider decision support, remote consultations; healthcare provider communication and training) and to a lesser extent for clients/ patients (e.g. client-to-client communication via online peer group support). No research on interventions for health system managers or administrators in palliative care was found. Using the WHO framework to situate research on DHIs in palliative care and identify gaps facilitates engagement with the wider health and social care sector and highlights the type of DHIs that may need to be prioritised for development and evaluation.

Telemedicine and related evidence gaps: Most of the evidence identified in this meta-review focused on telemedicine, specifically remote consultations via phone and video. This evidence is timely as the Covid-19 pandemic has pivoted attention towards these approaches. ${ }^{61}$ This metareview found that remote consultations are feasible in palliative care and generally acceptable to patients ${ }^{14,16,22,37}$ and caregivers. ${ }^{30,37}$ Remote consultations are perceived as particularly helpful when increasing access to care for families who are otherwise isolated by geography or housebound, ${ }^{14}$ reflecting the context for many patients and families due to social distancing requirements during the COVID pandemic. This should help reassure healthcare professionals that patients and caregivers often welcome these approaches, especially when face-to-face options are limited. While guidance regarding undertaking a remote consultation in palliative care is emerging, ${ }^{62}$ 
medRxiv preprint doi: https://doi.org/10.1101/2020.09.16.20195834; this version posted September 18, 2020. The copyright holder for this

It is made available under a CC-BY-NC-ND 4.0 International license .

evidence gaps remain. There is a need for research to determine when a face-to-face consultation is essential for terminally ill patients and when remote consultation is sufficient or preferred. Research is needed to understand contextual factors influencing the acceptability or effectiveness of remote consultations in palliative care ${ }^{49}$ and to shed light on inconsistent findings around symptom management. ${ }^{63}$ Critically, research on equitable access to palliative care delivered using DHIs is urgently needed to ensure that all those who need palliative care can benefit from it.

Palliative care research participation: Research involving people who are terminally ill is difficult due to the perceived vulnerability of the population and professional caution. ${ }^{40}$ Professional gatekeeping is a challenge, ${ }^{64}$ and biased samples consisting of patients who are mostly well or particularly motivated is often problematic. However there is ample evidence that many terminally

ill patients are interested in taking part in research and may benefit from doing so. ${ }^{65,66}$ As patients and caregivers grow accustomed to receiving care remotely, there will be more opportunities to engage patients and their families in research remotely, reducing burden and travel costs.

Providing a variety of ways in which patient and caregiver data can be collected, including online interviews and focus groups, maximises research participation, and is recommended.

\section{Conclusions}

DHIs are increasingly being implemented in the context of palliative care and the Covid-19 crisis has given this further impetus, particularly for clinical and supportive interventions at a distance. This meta-review has synthesised the corpus of research evidence represented by existing systematic reviews in this area. Overall, this indicates that DHIs are can be useful, safe, and 
acceptable to many terminally ill patients, their caregivers and staff involved in their care. DHIs are frequently used for education, symptom management, information sharing, decision-making and communication to improve quality of life without increasing costs. The evidence, though weak to moderate in quality, describes mostly positive impacts or no adverse effects. A greater emphasis on patient and caregiver outcomes is needed; and rapid research paradigms, evaluation and implementation studies now need to be prioritised. Future meta-reviews would benefit from looser inclusion criteria to capture other types of reviews containing evidence on emerging innovations such as wearables, smartphone apps, robotics and artificial intelligence. 


\section{Methods}

\section{Search Strategy}

The search strategy included the following databases: MEDLINE, MEDLINE In-Process \& Other Non-Indexed Citations; EMBASE, PsychINFO, CINAHL, Cochrane Database for Systematic Reviews (CDSR); Cochrane Database of Abstracts of Reviews of Effects (DARE); WHO Global Library (regional indexes only), and Web of Science. The Grey Literature Report (www.greylit.org) was also searched using keywords tailored for this database. The search strategy included MeSH headings and key words related to digital health, palliative care, and technology. All search strategies can be found in the supplementary material online (see Supplementary Material 2). Initial searches were conducted in June 2018; with update searches covering the period from June 2018 to January 2020 conducted in January 2020. Searches were limited to articles published after 2006 to ensure relevance given rapidly evolving technologies. There were no restrictions placed on language.

\section{Inclusion Criteria}

The search strategy targeted systematic reviews explicitly focused on DHIs in palliative care. Systematic reviews of broader healthcare areas which included and separately reported or synthesized studies of DHIs in palliative care were also eligible for inclusion. Using the PICO process, ${ }^{67}$ we defined our target population $(\mathbf{P})$ as children and adults who would benefit from palliative care, caregivers (informal and formal), and healthcare professionals delivering palliative care via DHIs or using DHIs to support palliative care decision-making. For the purposes of this review DHIs (I), were defined as approaches in which digital Information and Communication Technologies (ICT) are used to deliver, facilitate or augment palliative care services, including 
medRxiv preprint doi: https://doi.org/10.1101/2020.09.16.20195834; this version posted September 18, 2020. The copyright holder for this

It is made available under a CC-BY-NC-ND 4.0 International license .

psychological therapies, social support interventions, education, information, anticipatory care planning, remote care support, self-medication/management support, clinical decision support etc. Examples of relevant ICT include telephone, smartphone apps, mobile phones/SMS, videoconferencing, voice over IP (VoIP), instant messaging, email, internet resources, tablets, wearables, electronic patient records. Both synchronous (e.g. videoconferencing) and asynchronous (e.g. email) approaches were included. Our comparator of interest (C) was no DHIs or usual care. No limitations were placed on outcomes $(\mathbf{O})$, as we were interested in identifying the broad range of outcomes potentially influenced by palliative care DHIs.

\section{Data extraction}

The first and second authors (AF and $\mathrm{HO}$ ) undertook the database searches and initial screening of titles and abstracts. Where uncertainty existed in relation to potential eligibility, titles and abstracts were independently screened by a third author and ambiguities or disagreements resolved through discussion with the wider team. HO and AF independently assessed papers identified for full-text review, with CP arbitrating where it was unclear whether a review paper should be included.

Disagreements and uncertainties were resolved during full team discussions and the authors came to a $100 \%$ agreement.

Three co-authors extracted the following information from each of the included systematic reviews: authors, date of publication, country, review aims, search strategy, number of studies included, total number of participants, definition of palliative care, details of participants, functions and medium of DHIs included, reported outcomes, quality assessment methods and conclusions. Three co-authors team then extracted the types of digital health technologies and the intended purposes of the technologies from the individual studies from the included reviews and sought advice from to a fourth co-author in cases of uncertainty. 
All reviews were imported into NVivo. Findings from each review were thematically analysed.

These themes were then used to structure the results.

\section{Quality Appraisal}

The Assessment of Multiple Systematic Reviews (AMSTAR) checklist was used to critically appraise and score included reviews. ${ }^{68}$ For the purpose of this meta-review the following

thresholds were used: low (0-4), moderate (5-8), and high (9-11). ${ }^{69,70}$ Quality appraisal was conducted by four co-authors, with two co-authors independently rating each review. Where disagreements or uncertainties appeared, these were resolved through discussion with the wider team.

\section{Data Synthesis}

We expected substantial heterogeneity amongst systematic reviews as well as amongst the studies included within the reviews. Consequently, we planned to undertake a narrative synthesis. Interpretation was facilitated by discussion amongst the team. 


\section{Acknowledgements}

Thanks to Richard Meade, Marie Curie Head of Public Affairs in Scotland for helpful comments on a draft version of this manuscript. We are very grateful to Marshall Dozier at the University of Edinburgh for advice and assistance running the literature searches.

\section{Author Contributions}

AMF, HOD and CP designed the study. HOD developed the search strategy and conducted the literature searches. HOD, AMF, CS, and JL were involved in data screening and extraction. HOD and AMF synthesized findings and drafted the manuscript. All authors contributed to the final version.

\section{Declaration of competing interests}

The author(s) declared no potential conflicts of interest with respect to the research, authorship and/or publication of this article.

\section{Funding}

The author(s) disclosed that no financial support was provided for the research, authorship, and/or publication of this article. The posts of AMF and CS were funded by Marie Curie:

https://www.mariecurie.org.uk/ 


\section{References}

1 WHO. WHO Definition of Palliative Care, <http://www.who.int/cancer/palliative/definition/en/> (2016).

2 Murray, S. A. et al. Palliative care from diagnosis to death. BMJ 356, doi:10.1136/bmj.j878 (2017).

3 Gómez-Batiste, X. et al. Comprehensive and Integrated Palliative Care for People With Advanced Chronic Conditions: An Update From Several European Initiatives and Recommendations for Policy. Journal of Pain and Symptom Management 53, 509-517, doi:10.1016/j.jpainsymman.2016.10.361.

4 Powell, R. A. et al. Putting palliative care on the global health agenda. The Lancet Oncology 16, 131133, doi:10.1016/S1470-2045(15)70002-1.

5 Pagliari, C. et al. What Is eHealth (4): A Scoping Exercise to Map the Field. Journal of Medical Internet Research 7, e9, doi:10.2196/jmir.7.1.e9 (2005).

6 Food and Drug Administration (US). Digital Health. https://www.fda.gov/medical-devices/digitalhealth. Accessed on 27 August 2020., 2020).

7 Payne, S., Tanner, M. \& Hughes, S. Digitisation and the patient-professional relationship in palliative care. Palliative Medicine 34, 441-443, doi:10.1177/0269216320911501 (2020).

8 Kent, E. E. et al. What does 'palliative care' mean? Diverse definitions from cancer care providers. Journal of Clinical Oncology 34, 40-40, doi:10.1200/jco.2016.34.26_suppl.40 (2016).

9 Regnard, C. Using videoconferencing in palliative care. Palliative Medicine 14, 519-528, doi:10.1191/026921600701536444 (2000).

10 Leniz, J., Weil, A., Higginson, I. J. \& Sleeman, K. E. Electronic palliative care coordination systems (EPaCCS): a systematic review. BMJ Supportive \&amp; Palliative Care 10, 68-78, doi:10.1136/bmjspcare-2018-001689 (2020).

11 Holeman, I. et al. Mobile health for cancer in low to middle income countries: priorities for research and development. European journal of cancer care 23, 750-756, doi:10.1111/ecc.12250 (2014).

12 Taylor, J. \& Pagliari, C. The social dynamics of lung cancer talk on Twitter, Facebook and Macmillan.org.uk. npj Digital Medicine 2, 51, doi:10.1038/s41746-019-0124-y (2019).

13 Avati, A. et al. Improving palliative care with deep learning. BMC Med Inform Decis Mak 18, 122, doi:10.1186/s12911-018-0677-8 (2018).

14 Bradford, N., Armfield, N. R., Young, J. \& Smith, A. C. The case for home based telehealth in pediatric palliative care: a systematic review. BMC Palliative Care 12, 4, doi:https://dx.doi.org/10.1186/1472-684X-12-4 (2013).

15 Capurro, D., Ganzinger, M., Perez-Lu, J. \& Knaup, P. Effectiveness of eHealth interventions and information needs in palliative care: a systematic literature review. Journal of Medical Internet Research 16, e72 (2014).

16 Kidd, L., Cayless, S., Johnston, B. \& Wengstrom, Y. Telehealth in palliative care in the UK: a review of the evidence. Journal of Telemedicine \& Telecare 16, 394-402 (2010).

17 Oliver, D. P. et al. A systematic review of the evidence base for telehospice. Telemedicine Journal \& E-Health 18, 38-47 (2012).

18 Zheng, Y., Head, B. A. \& Schapmire, T. J. A Systematic Review of Telehealth in Palliative Care: Caregiver Outcomes. Telemed J E Health 22, 288-294, doi:10.1089/tmj.2015.0090 (2016).

19 Sleeman, K. E. et al. The escalating global burden of serious health-related suffering: projections to 2060 by world regions, age groups, and health conditions. The Lancet Global Health 7, e883-e892, doi:10.1016/S2214-109X(19)30172-X (2019).

20 Rogante, M., Giacomozzi, C., Grigioni, M. \& Kairy, D. Telemedicine in palliative care: a review of systematic reviews. Annali Dell'Istituto Superiore di Sanita 52, 434-442 (2016). 
Hailey, D. et al. The use and benefits of teleoncology (Structured abstract). Database of Abstracts of Reviews of Effects, 162 (2007). <http://onlinelibrary.wiley.com/o/cochrane/cldare/articles/DARE$12007008375 /$ frame.html>.

22 Zhou, M. et al. The utilization of telephone follow-up in the advanced cancer population: a review of the literature. Journal of Comparative Effectiveness Research 1, 509-517 (2012).

23 Allsop, M. J., Taylor, S., Mulvey, M. R., Bennett, M. I. \& Bewick, B. M. Information and communication technology for managing pain in palliative care: a review of the literature. $B M J$ support 5, 481-489 (2015).

24 Chi, N. C. \& Demiris, G. A systematic review of telehealth tools and interventions to support family caregivers. Journal of Telemedicine \& Telecare 21, 37-44 (2015). Ostherr, K., Killoran, P., Shegog, R. \& Bruera, E. Death in the Digital Age: A Systematic Review of Information and Communication Technologies in End-of-Life Care. J Palliat Med 19, 408-420 (2016). Willis, L., Demiris, G. \& Oliver, D. P. Internet use by hospice families and providers: a review. Journal of Medical Systems 31, 97-101 (2007).

27 Bush, R. A., Pérez, A., Baum, T., Etland, C. \& Connelly, C. D. A systematic review of the use of the electronic health record for patient identification, communication, and clinical support in palliative care. JAMIA open 1, 294, doi:10.1093/jamiaopen/ooy028 (2018). Huber, M. T., Highland, J. D., Krishnamoorthi, V. R. \& Tang, J. W.-Y. Utilizing the Electronic Health Record to Improve Advance Care Planning: A Systematic Review. 35, 532-541, doi:10.1177/1049909117715217 (2018). Smith, M. B. et al. The Use of Simulation to Teach Nursing Students and Clinicians Palliative Care and End-of-Life Communication: A Systematic Review. 35, 1140-1154, doi:10.1177/1049909118761386 (2018).

30 Zheng, Y., Head, B. A. \& Schapmire, T. J. A Systematic Review of Telehealth in Palliative Care: Caregiver Outcomes. Telemedicine Journal \& E-Health 22, 288-294 (2016).

31 Head, B. A., Schapmire, T. J. \& Zheng, Y. Telehealth in Palliative Care: A Systematic Review of Patient-Reported Outcomes. Journal of Hospice \& Palliative Nursing 19, 130-139, doi:10.1097/njh.0000000000000319 (2017).

32 Ngwenya, N. B. \& Mills, S. The use of weblogs within palliative care: a systematic literature review. Health Informatics J 20, 13-21 (2014).

33 Allsop, M. J., Powell, R. A. \& Namisango, E. The state of mHealth development and use by palliative care services in sub-Saharan Africa: a systematic review of the literature. BMJ support 8, 155-163, doi:https://dx.doi.org/10.1136/bmjspcare-2015-001034 (2018).

34 Hancock, S., Preston, N., Jones, H. \& Gadoud, A. Telehealth in palliative care is being described but not evaluated: a systematic review. BMC Palliative Care 18, doi:10.1186/s12904-019-0495-5 (2019). Leniz, J., Weil, A., Higginson, I. J. \& Sleeman, K. E. Electronic palliative care coordination systems (EPaCCS): a systematic review. BMJ support 10, 68-78, doi:10.1136/bmjspcare-2018-001689 (2020). Lemon, C., De Ridder, M. \& Khadra, M. Do Electronic Medical Records Improve Advance Directive Documentation? A Systematic Review. 36, 255-263, doi:10.1177/1049909118796191 (2019).

37 Jess, M., Timm, H. \& Dieperink, K. B. Video consultations in palliative care: A systematic integrative review. 33, 942-958, doi:10.1177/0269216319854938 (2019).

38 Taroco, A. L. C., Jr., Valente, T. C. O. \& Carbogim, C. S. Distance learning for updating health professionals in palliative care: a systematic review. BMJ support 7, 205-211 (2017).

39 Ngwenya, N. B. \& Mills, S. The use of weblogs within palliative care: a systematic literature review. Health Informatics Journal 20, 13-21 (2014). 

care research: An integrative qualitative evidence synthesis review. Palliative Medicine 33, 969984, doi:10.1177/0269216319858247 (2019).

41 Hoek, P. D., Schers, H. J., Bronkhorst, E. M., Vissers, K. C. P. \& Hasselaar, J. G. J. The effect of weekly specialist palliative care teleconsultations in patients with advanced cancer -a randomized clinical trial. BMC Medicine 15, 119, doi:10.1186/s12916-017-0866-9 (2017).

42 Meghani, S. H. et al. Clinician-Targeted Mobile Apps in Palliative Care: A Systematic Review. J Palliat Med 20, 1139-1147, doi:https://dx.doi.org/10.1089/jpm.2017.0070 (2017).

43 Pinto, S., Caldeira, S. \& Martins, J. C. e-Health in palliative care: review of literature, Google Play and App Store. International Journal of Palliative Nursing 23, 394-401, doi:https://dx.doi.org/10.12968/ijpn.2017.23.8.394 (2017).

44 Sutherland, A. E., Stickland, J. \& Wee, B. Can video consultations replace face-to-face interviews? Palliative medicine and the Covid-19 pandemic: rapid review. BMJ Supportive \&amp; Palliative Care, bmjspcare-2020-002326, doi:10.1136/bmjspcare-2020-002326 (2020).

45 Steindal, S. A. et al. Patients' Experiences of Telehealth in Palliative Home Care: Scoping Review. J Med Internet Res 22, e16218, doi:10.2196/16218 (2020).

46 Jandoo, T. WHO guidance for digital health: What it means for researchers. DIGITAL HEALTH 6, 2055207619898984, doi:10.1177/2055207619898984 (2020).

47 Brereton, L. et al. What do we know about different models of providing palliative care? Findings from a systematic review of reviews. Palliative Medicine 31, 781-797, doi:10.1177/0269216317701890 (2017).

48 Ekeland, A. G., Bowes, A. \& Flottorp, S. Effectiveness of telemedicine: A systematic review of reviews. International Journal of Medical Informatics 79, 736-771, doi:10.1016/j.ijmedinf.2010.08.006 (2010).

49 Elbert, N. J. et al. Effectiveness and Cost-Effectiveness of eHealth Interventions in Somatic Diseases: A Systematic Review of Systematic Reviews and Meta-Analyses. 16, doi:10.2196/jmir.2790 (2014).

50 Black, A. D. et al. The Impact of eHealth on the Quality and Safety of Health Care:A Systematic Overview. Black , A D, Car , J , Pagliari , C, Anandan, C, Cresswell , K, Bokun, T, McKinstry , B, Procter , R, Majeed , A \& Sheikh , A 2011, 'The Impact of eHealth on the Quality and Safety of Health Care : A Systematic Overview ', PLOS Medicine , vol. 8, no. 1, e1000387. https://doi.org/10.1371/journal.pmed.1000387, doi:https://doi.org/10.1371/journal.pmed.1000387 (2011).

51 Iribarren, S. J., Cato, K., Falzon, L. \& Stone, P. W. What is the economic evidence for mHealth? A systematic review of economic evaluations of mHealth solutions.(Report). PLoS ONE 12, e0170581, doi:10.1371/journal.pone.0170581 (2017).

52 Vimalananda, V. G. et al. Electronic consultations (E-consults) and their outcomes: a systematic review. Journal of the American Medical Informatics Association : JAMIA 27, doi:10.1093/jamia/ocz185 (2019).

53 Glasgow, R. E., Phillips, S. M. \& Sanchez, M. A. Implementation science approaches for integrating eHealth research into practice and policy. International Journal of Medical Informatics 83, e1-e11, doi:https://doi.org/10.1016/j.ijmedinf.2013.07.002 (2014).

54 Ross, J., Stevenson, F., Lau, R. \& Murray, E. Factors that influence the implementation of e-health: a systematic review of systematic reviews (an update). Implementation Science 11, 146, doi:10.1186/s13012-016-0510-7 (2016).

55 Daveson, B. A. et al. Results of a transparent expert consultation on patient and public involvement in palliative care research. Palliative Medicine 29, 939-949, doi:10.1177/0269216315584875 (2015). 
Bienfait, F., Petit, M., Pardenaud, R., Guineberteau, C. \& Pignon, A. Applying M-Health to Palliative Care: A Systematic Review on the Use of M-Health in Monitoring Patients With Chronic Diseases and its Transposition in Palliative Care. American Journal of Hospice and Palliative Medicine ${ }^{\circledR}$ 37, 549-564, doi:10.1177/1049909119885655 (2020).

57 Reddy, S., Fox, J. \& Purohit, M. P. Artificial intelligence-enabled healthcare delivery. Journal of the Royal Society of Medicine, 141076818815510, doi:10.1177/0141076818815510 (2018).

58 Avati, A. et al. Improving palliative care with deep learning. bmc medical informatics and decision making 18, 55-64, doi:10.1186/S12911-018-0677-8 (2018).

59 Nwosu, A. C. et al. Robotic technology for palliative and supportive care: Strengths, weaknesses, opportunities and threats. Palliative Medicine 33, 1106-1113, doi:10.1177/0269216319857628 (2019).

60 World Health Organization. Classification of digital health interventions. (World Health Organization, Geneva. WHO/RHR/18.06, 2018).

61 Bestsennyy, O., Gilbert, G., Harris, A. \& Rost, J. Telehealth: A quarter-trillion-dollar post-COVID-19 reality? https://www.mckinsey.com/industries/healthcare-systems-and-services/ourinsights/telehealth-a-quarter-trillion-dollar-post-covid-19-reality\#. Insights on Healthcare Systems \& Services. McKinsey and Company (2020).

62 Calton, B., Abedini, N. \& Fratkin, M. Telemedicine in the Time of Coronavirus. J Pain Symptom Manage 60, e12-e14, doi:10.1016/j.jpainsymman.2020.03.019 (2020).

63 Slev, V. N. et al. Effects of eHealth for patients and informal caregivers confronted with cancer: A meta-review. International Journal of Medical Informatics 87, 54-67, doi:10.1016/j.ijmedinf.2015.12.013 (2016).

64 Kars, M. C. et al. A systematic review of reasons for gatekeeping in palliative care research. Palliative Medicine 30, 533-548, doi:10.1177/0269216315616759 (2015).

65 Gysels, M. H., Evans, C. \& Higginson, I. J. Patient, caregiver, health professional and researcher views and experiences of participating in research at the end of life: a critical interpretive synthesis of the literature. BMC Medical Research Methodology 12, 123, doi:10.1186/1471-2288-12-123 (2012).

66 Middlemiss, T., Lloyd-Williams, M., Laird, B. J. \& Fallon, M. T. Symptom Control Trials in Patients With Advanced Cancer: A Qualitative Study. Journal of pain and symptom management 50, 642649.e641, doi:10.1016/j.jpainsymman.2015.05.009 (2015).

67 Schardt, C., Adams, M. B., Owens, T., Keitz, S. \& Fontelo, P. Utilization of the PICO framework to improve searching PubMed for clinical questions. BMC Medical Informatics and Decision Making 7, 16, doi:10.1186/1472-6947-7-16 (2007).

68 Shea, B. J. et al. Development of AMSTAR: a measurement tool to assess the methodological quality of systematic reviews. BMC Medical Research Methodology 7, 1-7, doi:10.1186/1471-22887-10 (2007).

69 Jaspers, M. W., Smeulers, M., Vermeulen, H. \& Peute, L. W. Effects of clinical decision-support systems on practitioner performance and patient outcomes: a synthesis of high-quality systematic review findings. Journal of the American Medical Informatics Association : JAMIA 18, 327-334, doi:10.1136/amiajnl-2011-000094 (2011).

70 Sequeira-Byron, P., Fedorowicz, Z., Jagannath, V. A. \& Sharif, M. O. An AMSTAR assessment of the methodological quality of systematic reviews of oral healthcare interventions published in the Journal of Applied Oral Science (JAOS). Journal of applied oral science : revista FOB 19, 440-447 (2011). 


\section{APPENDICES}

Table 1: Characteristics of the included systematic reviews ( $N=21)$

\begin{tabular}{|c|c|c|c|c|c|}
\hline Review & $\begin{array}{l}\text { Country of } \\
\text { institution }\end{array}$ & Broad area & Review aims & $\begin{array}{l}\text { No. of included PC studies and } \\
\text { types of studies }\end{array}$ & Type of DHIs included \\
\hline $\begin{array}{l}\text { Willis et al. } \\
\text { (2007) }\end{array}$ & USA & Internet & $\begin{array}{l}\text { To examine internet use by } \\
\text { hospice patients, their families, } \\
\text { and hospice professionals. }\end{array}$ & $\begin{array}{l}6 \text { studies included } \\
* \text { case study }(n=1) \\
* \text { questionnaire }(n=1) \\
* \text { internet surveys }(n=2) \\
* \text { descriptive narrative }(n=1) \\
* \text { review of case studies \& } \\
\text { survey }(n=1)\end{array}$ & $\begin{array}{l}* \text { videophone } \\
* \text { digital pens } \\
* \text { online survey } \\
* \text { online chat room }\end{array}$ \\
\hline $\begin{array}{l}\text { Kidd et al. } \\
\text { (2010) }\end{array}$ & UK & Telehealth & $\begin{array}{l}\text { To determine who is using } \\
\text { telehealth and to what ends, } \\
\text { and if the use of telehealth is } \\
\text { increasing in the clinical setting. }\end{array}$ & $\begin{array}{l}21 \text { studies included } \\
* \text { descriptive }(n=9) \\
\text { * pilot }(n=3) \\
\text { * service evaluation }(n=1) \\
\text { * system report }(n=1) \\
\text { * web resource }(n=1) \\
\text { * mixed methods }(n=1) \\
\text { * prospective cohort }(n=1) \\
\text { * qualitative }(n=1) \\
\text { * case study }(n=1) \\
* \text { not given }(n=2)\end{array}$ & $\begin{array}{l}\text { * videoconferencing } \\
\text { * hand-held personal computer } \\
\text { * mobile phone } \\
\text { * website } \\
\text { * electronic records } \\
\text { * e-learning resource } \\
\text { *out-of-hours telephone advice } \\
\text { and support services } \\
\text { * computer-based screening } \\
\text { system } \\
\text { * computerised system } \\
\text { * NHS intranet }\end{array}$ \\
\hline
\end{tabular}




\begin{tabular}{|c|c|c|c|c|c|}
\hline $\begin{array}{l}\text { Parker } \\
\text { Oliver et al. } \\
(2012)\end{array}$ & USA & Telehospice & $\begin{array}{l}\text { To examine the evidence } \\
\text { concerning tele-hospice services. }\end{array}$ & $\begin{array}{l}26 \text { studies included } \\
\text { * surveys }(n=6) \\
\text { * mixed methods }(n=10) \\
\text { * interviews }(n=4) \\
\text { * not given }(n=1) \\
\text { * focus group }(n=1) \\
\text { * cost analysis }(n=1) \\
\text { * record review }(n=1) \\
\text { * content analysis (videotapes) } \\
(n=1) \\
* \text { observation }(n=1)\end{array}$ & $\begin{array}{l}\text { * telephone advice line } \\
* \text { videophones } \\
* \text { tele-hospice (technology not } \\
\text { specified) } \\
\text { * PDAs } \\
\text { * computers \& internet }\end{array}$ \\
\hline $\begin{array}{l}\text { Zhou et al. } \\
\text { (2012) }\end{array}$ & Canada & Telephone & $\begin{array}{l}\text { To examine the use of telephone } \\
\text { follow-ups compared with } \\
\text { clinical follow-ups in advanced } \\
\text { cancer patients receiving } \\
\text { palliative care }\end{array}$ & $\begin{array}{l}11 \text { studies included } \\
\text { * individual study designs not } \\
\text { provided }\end{array}$ & $\begin{array}{l}\text { * telephone follow-up } \\
\text { consultations }\end{array}$ \\
\hline $\begin{array}{l}\text { Bradford et } \\
\text { al. (2013) }\end{array}$ & Australia & Telehealth & $\begin{array}{l}\text { To examine the research of } \\
\text { home-based tele-Health in } \\
\text { paediatric PC. }\end{array}$ & $\begin{array}{l}33 \text { studies included } \\
* \text { reviews }(n=4) \\
\text { *RCTs }(n=4) \\
* \text { cohort studies }(n=2) \\
\text { * chart reviews }(n=2) \\
* \text { cost comparison }(n=1) \\
* \text { quantitative survey }(n=1) \\
\text { * quantitative }(n=1) \\
* \text { mixed methods }(n=2) \\
\text { * qualitative }(n=15) \\
\text { * cost benefit analysis / } \\
\text { qualitative }(n=1)\end{array}$ & $\begin{array}{l}\text { * videoconferencing } \\
\text { * videophones } \\
* \text { SMS text message } \\
* \text { tele-Health } \\
* \text { telemedicine } \\
* \text { tele-hospice }\end{array}$ \\
\hline
\end{tabular}




\begin{tabular}{|c|c|c|c|c|c|}
\hline $\begin{array}{l}\text { Capurro et } \\
\text { al. (2014) }\end{array}$ & Chile & $\begin{array}{l}\text { Telehealth - } \\
\text { asynchronous } \\
\text { devices only }\end{array}$ & $\begin{array}{l}\text { To identify eHealth interventions } \\
\text { in PC and to determine the } \\
\text { information requirements for } \\
\text { patients, family members, and } \\
\text { professionals in PC. }\end{array}$ & $\begin{array}{l}17 \text { studies included } \\
* \text { quasi-experimental }(n=3) \\
\text { * observational; cross-sectional } \\
\text { ( } n=11) \\
* \text { qualitative inquiry }(n=2) \\
* \text { report }(n=1)\end{array}$ & $\begin{array}{l}* \text { internet chat rooms } \\
* \text { mobile phones } \\
\text { * reporting software } \\
\text { * digital pens } \\
\text { * surveys } \\
\text { * telephone support } \\
\text { * PDAs } \\
\text { * telehomecare }\end{array}$ \\
\hline $\begin{array}{l}\text { Ngwenya } \\
\text { and Mills } \\
(2014)\end{array}$ & UK & Weblogs & $\begin{array}{l}\text { To review evidence for benefits } \\
\text { and disadvantages of weblogs in } \\
\text { PC. }\end{array}$ & $\begin{array}{l}6 \text { studies included } \\
* \text { online survey }(n=2) \\
* \text { case report }(n=2) \\
* \text { descriptive experimental } \\
\text { study }(n=1) \\
* \text { analysis of blog posts }(n=1)\end{array}$ & $\begin{array}{l}* \text { internet blogs } \\
* \text { online survey }\end{array}$ \\
\hline $\begin{array}{l}\text { Allsop et al. } \\
(2015)\end{array}$ & UK & $\begin{array}{l}\text { ICT systems } \\
\text { in general }\end{array}$ & $\begin{array}{l}\text { To review existing Information } \\
\text { and Communication Technology } \\
\text { (ICT) systems created for pain } \\
\text { management in oncology } \\
\text { patients in PC. }\end{array}$ & $\begin{array}{l}24 \text { studies included } \\
* \text { randomised experiment }(n=3) \\
* \text { non-randomised experiment } \\
(n=1) \\
* \text { survey design }(n=2) \\
\text { * observational }(n=1) \\
* \text { expert opinion }(n=1) \\
\text { *non-experimental }(n=13) \\
\text { * description of system }(n=2) \\
\text { *Not described }(n=1)\end{array}$ & $\begin{array}{l}* \text { tablet computer } \\
* \text { web-application software } \\
* \text { computer } \\
* \text { telephone } \\
* \text { handheld device } \\
* \text { mobile phone } \\
* \text { internet } \\
\text { * tablet } \\
\text { * PDA } \\
\text { * interactive touch screen } \\
* \text { online surveys } \\
\text { * pen tablet } \\
* \text { computer software } \\
* \text { voice-recorded telephone calls } \\
* \text { digital pen \& pain diary } \\
* \text { e-tablet }\end{array}$ \\
\hline
\end{tabular}




\begin{tabular}{|c|c|c|c|c|c|}
\hline $\begin{array}{l}\text { Chi and } \\
\text { Demiris } \\
\text { (2015) }\end{array}$ & USA & Telehealth & $\begin{array}{l}\text { To review the effects of } \\
\text { telehealth applications on } \\
\text { caregivers. (A subset of studies } \\
\text { were PC focused) }\end{array}$ & $\begin{array}{l}5 \text { studies included } \\
* \text { quasi-experimental }(n=2) \\
* \text { comparison case study }(n=1) \\
* \text { pilot-controlled trial without } \\
\text { randomisation }(n=1) \\
* 1 \text { RCT }\end{array}$ & $\begin{array}{l}\text { * videophones } \\
* \text { home telehealth service }\end{array}$ \\
\hline $\begin{array}{l}\text { Ostherr et } \\
\text { al. (2016) }\end{array}$ & USA & $\begin{array}{l}\text { ICT systems } \\
\text { in general }\end{array}$ & $\begin{array}{l}\text { To review the use of ICTs in end } \\
\text { of life care for communication } \\
\text { between clinicians, patients and } \\
\text { their families. }\end{array}$ & $\begin{array}{l}38 \text { studies included } \\
\text { * RCT }(n=17) \\
\text { * pre-post interventions }(n=18) \\
\text { * interrupted time series }(n=2) \\
\text { * prospective cohort study } \\
(n=1)\end{array}$ & $\begin{array}{l}\text { * videos } \\
* \text { online support system } \\
\text { * online education } \\
\text { * prototype websites } \\
\text { * videoconferencing } \\
\text { * computer-based multimedia } \\
\text { decision tool } \\
\text { * CD } \\
\text { * telephones } \\
\text { * videotape } \\
\text { * SMS text messaging } \\
\text { * telemonitoring } \\
\text { * web-based PC report card } \\
\text { * fax } \\
\text { * palm pilot }\end{array}$ \\
\hline
\end{tabular}




\begin{tabular}{|c|c|c|c|c|c|}
\hline $\begin{array}{l}\text { Zheng et al. } \\
(2016)\end{array}$ & USA & Telehealth & $\begin{array}{l}\text { To review telehealth } \\
\text { interventions on caregivers in } \\
\text { palliative care settings. }\end{array}$ & $\begin{array}{l}9 \text { studies included } \\
\text { * prospective cohort }(n=1) \\
* \text { mixed methods }(n=2) \\
\text { * pooled analysis of } 2 \text { RCTs } \\
(n=1) \\
\text { * non-randomized pre-post test } \\
(n=1) \\
\text { * pilot study ( } n=1) \\
\text { * mixed methods case study } \\
(n=1) \\
\text { * randomised noninferiority } \\
\text { study }(n=1) \\
\text { * feasibility study }(n=1)\end{array}$ & $\begin{array}{l}\text { * home telehealth consultations } \\
* \text { videophones } \\
* \text { telehealth } \\
\text { * online support system } \\
* \text { telephones }\end{array}$ \\
\hline $\begin{array}{l}\text { Head et al. } \\
\text { (2017) }\end{array}$ & USA & Telehealth & $\begin{array}{l}\text { To describe patient-reported } \\
\text { outcomes in telehealth studies } \\
\text { for palliative care }\end{array}$ & $\begin{array}{l}11 \text { studies included } \\
\text { *RCT with pre-test and post-test } \\
\text { design }(n=1) \\
\text { *quantitative survey }(n=1) \\
\text { *mixed methods }(n=1) \\
\text { *mixed methods with semi- } \\
\text { structured interviews }(n=1) \\
\text { *qualitative case study }(n=1) \\
\text { *case study ( } n=1) \\
\text { *mixed methods case study } \\
(n=1) \text { * pre/post survey }(n=1) \\
\text { *case report }(n=1) \text { randomized } \\
\text { *non inferiority trial }(n=1) \\
\text { *two-group non- randomised } \\
\text { study (n=1) }\end{array}$ & $\begin{array}{l}\text { * telephone } \\
* \text { WhatsApp } \\
\text { * videophones } \\
\text { * text messaging } \\
\text { * mobile phone-based symptom } \\
\text { assessment software } \\
\text { * home telehealth monitoring } \\
\text { * Rexnet - computer program to } \\
\text { enable text messages between } \\
\text { nurses and patients }\end{array}$ \\
\hline $\begin{array}{l}\text { Taroco et } \\
\text { al. (2017) }\end{array}$ & Brazil & Internet & $\begin{array}{l}\text { To review online educational PC } \\
\text { programs to update health } \\
\text { professionals }\end{array}$ & $\begin{array}{l}14 \text { studies included } \\
\text { Types of studies not provided. }\end{array}$ & $\begin{array}{l}\text { * video conference } \\
\text { * internet }\end{array}$ \\
\hline
\end{tabular}




\begin{tabular}{|c|c|c|c|c|c|}
\hline $\begin{array}{l}\text { Allsop et al. } \\
\text { (2018) }\end{array}$ & UK & mHealth & $\begin{array}{l}\text { To identify the use and } \\
\text { development of mHealth in PC } \\
\text { in sub-Saharan Africa. }\end{array}$ & $\begin{array}{l}5 \text { studies included } \\
\text { * Rapid evaluation methodology } \\
(n=1) \\
\text { *Interviews ( } n=1) \\
\text { * Survey and follow-up interview } \\
\text { ( } n=1) \\
\text { *Pre-and post-test survey }(n=1) \\
\text { *Mixed method }(n=1)\end{array}$ & $\begin{array}{l}\text { * mobile phones } \\
\text { * email } \\
\text { * telephone } \\
\text { * electronic health system } \\
\text { * instant messaging } \\
\text { * blog } \\
\text { * text messages }\end{array}$ \\
\hline $\begin{array}{l}\text { Bush et al } \\
(2018)\end{array}$ & USA & $\begin{array}{l}\text { Electronic } \\
\text { Health } \\
\text { Records }\end{array}$ & $\begin{array}{l}\text { To determine whether } \\
\text { Electronic Health Records (EHRs) } \\
\text { and related Clinical Decision } \\
\text { Supports facilitate PC. }\end{array}$ & $\begin{array}{l}30 \text { studies included } \\
\text { *Feasibility }(n=9) \\
\text { * Retrospective cohort analysis } \\
\text { ( } n=5) \\
\text { * Mixed methods }(n=5) \\
\text { *Secondary analysis }(n=4) \\
\text { *Surveys }(n=2) \\
\text { *Qualitative interviews }(n=3) \\
\text { * Retrospective analysis }(n=1) \\
\text { *Pilot }(n=1)\end{array}$ & Electronic Health Records \\
\hline $\begin{array}{l}\text { Smith et al } \\
(2018)\end{array}$ & USA & Simulators & $\begin{array}{l}\text { To review the use of simulation- } \\
\text { based learning experiences } \\
\text { (SBLEs) to teach communication } \\
\text { skills to nursing students and } \\
\text { clinicians who provide palliative } \\
\text { and end-of-life care to patients } \\
\text { and their families. }\end{array}$ & $\begin{array}{l}30 \text { studies included } \\
\text { * Not described }\end{array}$ & $\begin{array}{l}* \text { high fidelity and medium fidelity } \\
\text { simulators } \\
* \text { video }\end{array}$ \\
\hline
\end{tabular}




\begin{tabular}{|c|c|c|c|c|c|}
\hline $\begin{array}{l}\text { Huber et al } \\
(2018)\end{array}$ & USA & $\begin{array}{l}\text { Electronic } \\
\text { Health } \\
\text { Records }\end{array}$ & $\begin{array}{l}\text { To review the literature for } \\
\text { electronic health record (EHR) } \\
\text { interventions to improve ACP } \\
\text { documentation; To describe } \\
\text { the EHR components of these } \\
\text { interventions; To identify } \\
\text { populations in which the } \\
\text { interventions were } \\
\text { implemented; To assess the } \\
\text { efficacy of the interventions in } \\
\text { these populations. }\end{array}$ & $\begin{array}{l}16 \text { Studies included } \\
{ }^{*} \text { Comparative analyses }(n=9) \\
\text { *RCT }(n=1) \\
\text { *non-randomized trials }(n=3) \\
\text { *Pre-post analyses }(n=3)\end{array}$ & *electronic Health Records \\
\hline $\begin{array}{l}\text { Hancock et } \\
\text { al (2019) }\end{array}$ & UK & Telehealth & $\begin{array}{l}\text { To describe the current use of } \\
\text { telehealth in palliative care in } \\
\text { the UK and evaluate telehealth } \\
\text { initiatives against a digital } \\
\text { service standard. } \\
\text { To explore whether telehealth } \\
\text { results in a reduction in } \\
\text { emergency care access }\end{array}$ & $\begin{array}{l}30 \text { papers relating to } \mathbf{2 7} \\
\text { studies. } \\
\text { *Qualitative }(n=7) \\
\text { *Service evaluations ( } n=4) \\
\text { * Randomized controlled trials } \\
\text { ( } n=3 \text { ) } \\
\text { *Protocols }(n=3) \\
\text { *Descriptive }(n=3) \\
\text { * Randomized crossover trial } \\
\text { ( } n=1 \text { ) } \\
\text { *Mixed methods ( } n=2) \\
\text { * Realist evaluation ( } n=1) \\
\text { *Prospective interventional } \\
\text { ( } n=1) \\
\text { *Prospective longitudinal } \\
\text { cohort ( } n=1 \text { ) } \\
\text { *2 Prospective observational } \\
\text { ( } n=2 \text { ) } \\
\text { *2 Retrospective observational } \\
\text { ( } n=2)\end{array}$ & $\begin{array}{l}\text { *home telemonitoring } \\
\text { *videoconferencing } \\
\text { *telephone advice line } \\
\text { *electronic patient records } \\
\text { *tablets/apps }\end{array}$ \\
\hline
\end{tabular}




\begin{tabular}{|c|c|c|c|c|c|}
\hline $\begin{array}{l}\text { Jess et al } \\
(2019)\end{array}$ & Denmark & $\begin{array}{l}\text { Video- } \\
\text { consultations }\end{array}$ & $\begin{array}{l}\text { To review evidence for video } \\
\text { consultations in palliative care } \\
\text { from the perspective of patients } \\
\text { and relatives, health care } \\
\text { professionals, and society. }\end{array}$ & $\begin{array}{l}39 \text { articles included. } \\
\text { *mixed methods }(n=14) \\
\text { *qualitative }(n=10) \\
\text { *quantitative }(n=10) \text { including } \\
\text { one RCT } \\
\text { *case studies }(n=5) .\end{array}$ & *Video-consultations \\
\hline $\begin{array}{l}\text { Leniz et al } \\
\text { (2019) }\end{array}$ & UK & $\begin{array}{l}\text { Electronic } \\
\text { Health } \\
\text { Records }\end{array}$ & $\begin{array}{l}\text { To review evidence on electronic } \\
\text { palliative care co-ordination } \\
\text { systems (EPaCCS), in order to } \\
\text { identify gaps in the evidence and } \\
\text { make recommendations for } \\
\text { policy } \\
\text { and research. }\end{array}$ & $\begin{array}{l}12 \text { studies included } \\
\text { *observational studies ( } n=9) \\
\text { *qualitative studies }(n=2) \\
\text { *mixed-method }(n=1) . \\
\text { (18 opinion pieces and reports } \\
\text { excluded) }\end{array}$ & $\begin{array}{l}\text { *Electronic palliative care } \\
\text { coordination systems }\end{array}$ \\
\hline $\begin{array}{l}\text { Lemon et al } \\
\text { (2019) }\end{array}$ & Australia & $\begin{array}{l}\text { Electronic } \\
\text { Health } \\
\text { Records }\end{array}$ & $\begin{array}{l}\text { To identify and evaluate the } \\
\text { evidence for using EMRs } \\
\text { (electronic medical records) in } \\
\text { documenting advanced } \\
\text { directives (AD) and identifying } \\
\text { implications of the findings for } \\
\text { addressing challenges in their } \\
\text { use. }\end{array}$ & $\begin{array}{l}15 \text { studies } \\
* 4 \text { Pre-post } \\
\text { *4 cross-sectional } \\
\text { *2 retrospective } \\
\text { *1 RCT } \\
\text { *1 RCT pilot } \\
\text { *1 historical control } \\
\text { *1 retrospective cohort } \\
\text { *1 Evaluation of EMR }\end{array}$ & Electronic Medical Records (EMRs) \\
\hline
\end{tabular}


Table 4: Overall quality and findings from the included systematic reviews $(\mathrm{N}=21)$

\begin{tabular}{|c|c|c|c|c|c|}
\hline Review & $\begin{array}{l}\text { AMSTAR } \\
\text { score }\end{array}$ & $\begin{array}{l}\text { Critical } \\
\text { appraisal tools } \\
\text { used }\end{array}$ & $\begin{array}{l}\text { Quality of } \\
\text { included studies }\end{array}$ & Findings & Summary \\
\hline $\begin{array}{l}\text { Willis et al. } \\
\text { (2007) }\end{array}$ & 2 & None & Not assessed. & $\begin{array}{l}\text { * improved communication } \\
\text { between patients, caregivers, and } \\
\text { professionals } \\
* \text { improves continuity of care } \\
\text { * patients perceived improved } \\
\text { quality of care } \\
\text { * reasons for health professionals } \\
\text { to use internet: email, online } \\
\text { journals, finding clinical information } \\
\text { * patients seek information online } \\
\text { about their illness and alternative } \\
\text { treatments } \\
\text { * patients like the anonymity of } \\
\text { online support groups }\end{array}$ & $\begin{array}{l}\text { Internet-based interventions are } \\
\text { effective for patients and } \\
\text { professionals who use the web to } \\
\text { search for answers to medical } \\
\text { questions, deliver interventions, } \\
\text { and for communication purposes. } \\
\text { However, quality of evidence was } \\
\text { not assessed. }\end{array}$ \\
\hline $\begin{array}{l}\text { Kidd et al. } \\
\text { (2010) }\end{array}$ & 4 & None & Not assessed & $\begin{array}{l}\text { * improved continuity of care } \\
\text { * improved clinical effectiveness } \\
\text { * reduced costs } \\
\text { * effective use of resources } \\
\text { * useful for education and } \\
\text { disseminating practice guidelines } \\
\text { * acceptable to patients and health } \\
\text { professionals } \\
\text { * feasible alternative when } \\
\text { distance, time, and costs are } \\
\text { restraints } \\
\text { * lack of evidence-based research }\end{array}$ & $\begin{array}{l}\text { Patients and health professionals } \\
\text { find DHIs acceptable and usable in } \\
\text { palliative care. Preliminary } \\
\text { evidence for effectiveness though } \\
\text { barriers remain to integrating DHIs } \\
\text { into routine practice. Quality of } \\
\text { evidence was not assessed. }\end{array}$ \\
\hline
\end{tabular}




\begin{tabular}{|c|c|c|c|c|c|}
\hline $\begin{array}{l}\text { Parker } \\
\text { Oliver et al. } \\
(2012)\end{array}$ & 4 & $\begin{array}{l}\text { Two-part self- } \\
\text { developed } \\
\text { scoring } \\
\text { framework }\end{array}$ & $\begin{array}{l}\text { Mean quality } \\
\text { score for } \\
\text { quantitative } \\
\text { studies was } 9.2 \\
\text { (range 5-14), } \\
\text { representing } \\
\text { medium-high } \\
\text { strength of } \\
\text { evidence. } \\
\text { Mean quality } \\
\text { score for } \\
\text { qualitative } \\
\text { studies was } 9 \\
\text { out of } 11 \text {, } \\
\text { representing } \\
\text { medium to high } \\
\text { strength of } \\
\text { evidence. }\end{array}$ & $\begin{array}{l}\text { * hospice providers supportive of } \\
\text { tele-hospice technologies } \\
\text { * no study was large enough to } \\
\text { demonstrate significant differences } \\
\text { in patient anxiety, caregiver QOL, } \\
\text { communication, anxiety, and } \\
\text { caregiver thoughts on pain } \\
\text { medication } \\
\text { * majority of studies were small, } \\
\text { reflecting fledgling nature of } \\
\text { research area } \\
\text { * barriers to implementation: } \\
\text { included gatekeeping and variation } \\
\text { in staff member's readiness and } \\
\text { ability to use DHIs. }\end{array}$ & $\begin{array}{l}\text { Studies have evaluated the use of a } \\
\text { variety of technologies, attitudes } \\
\text { toward use by providers and } \\
\text { consumers, clinical outcomes, } \\
\text { barriers, readiness, and cost. } \\
\text { The evidence base, although } \\
\text { growing and promising, is of mixed } \\
\text { scientific rigor with lower-medium } \\
\text { strength evidence in quantitative } \\
\text { studies and medium-higher } \\
\text { strength evidence in qualitative } \\
\text { studies. Barriers to implementation } \\
\text { were evident. }\end{array}$ \\
\hline $\begin{array}{l}\text { Zhou et al. } \\
\text { (2012) }\end{array}$ & 3 & None & Not assessed & $\begin{array}{l}\text { * feasible to take clinical } \\
\text { information over the phone } \\
\text { * minimised burden on patient to } \\
\text { attend clinics } \\
\text { *maintained QOL } \\
\text { * poor accrual in clinical studies } \\
\text { noted as a problem in advanced } \\
\text { cancer populations } \\
\text { *attrition rates still a problem with } \\
\text { telephone follow-ups } \\
\text { * reduces burden on care facility } \\
\text { * improves contact with poor } \\
\text { performance status patients } \\
\text { * positive opinion of intervention in } \\
\text { general and no disadvantages were }\end{array}$ & $\begin{array}{l}\text { Telephone follow-ups provide an } \\
\text { acceptable and feasible alternative } \\
\text { to in-person clinical follow-ups for } \\
\text { assessing patient symptoms, } \\
\text { decreasing burden, and enabling } \\
\text { quality of life to be maintained. } \\
\text { Quality of evidence was not } \\
\text { assessed. }\end{array}$ \\
\hline
\end{tabular}




\begin{tabular}{|c|c|c|c|c|c|}
\hline & & & & $\begin{array}{l}\text { noted } \\
\text { * combining in-person clinical } \\
\text { follow ups and telephone follow- } \\
\text { ups could provide a more complete } \\
\text { assessment }\end{array}$ & \\
\hline $\begin{array}{l}\text { Bradford et } \\
\text { al. (2013) }\end{array}$ & 5 & $\begin{array}{l}\text { Critical } \\
\text { Appraisal Skills } \\
\text { Programme } \\
\text { (CASP) }\end{array}$ & $\begin{array}{l}\text { Moderate to } \\
\text { high. } \\
\text { CASP scores } \\
\text { ranging from } 4 / 8 \\
\text { to } 11 / 11 \\
\text { depending on } \\
\text { study design. }\end{array}$ & $\begin{array}{l}\text { * Home telehealth generally } \\
\text { acceptable for families and } \\
\text { clinicians as part of the palliative } \\
\text { care provided } \\
\text { * feasible for delivering care } \\
\text { * effects on QOL and anxiety } \\
\text { positive overall } \\
\text { * decrease in parental anxiety } \\
\text { * increased confidence levels of } \\
\text { families } \\
\text { * some evidence for cost- } \\
\text { effectiveness } \\
\text { * no adverse effects } \\
\text { * improves access to care } \\
\text { * reduces travel costs for patients } \\
\text { and caregivers } \\
\text { * issues: impersonal, no human } \\
\text { contact, financial issues regarding } \\
\text { reimbursement } \\
\text { * economic limit to eHealth } \\
\text { interventions if intervention } \\
\text { supplements rather than replaces } \\
\text { the standard care } \\
\text { * barriers to use: clinicians are } \\
\text { gatekeepers and healthcare settings } \\
\text { need to be ready for eHealth } \\
\text { interventions } \\
\text { *implementation: must fully engage }\end{array}$ & $\begin{array}{l}\text { Studies generally identified benefits } \\
\text { of using } \\
\text { home telehealth in palliative care } \\
\text { and overall evidence was judged } \\
\text { moderate to high quality. However, } \\
\text { research on DHIs in paediatric } \\
\text { palliative care is challenging. More } \\
\text { research is needed to assess what } \\
\text { influences acceptance of these } \\
\text { DHIs, including ease of utilizing the } \\
\text { technology and care goals }\end{array}$ \\
\hline
\end{tabular}




\begin{tabular}{|c|c|c|c|c|c|}
\hline & & & & $\begin{array}{l}\text { with all staff and patients, patient } \\
\text { centred approach, and clinician to } \\
\text { champion eHealth } \\
\text { * Several methodological challenges } \\
\text { in conducting research in paediatric } \\
\text { palliative care. }\end{array}$ & \\
\hline $\begin{array}{l}\text { Capurro et } \\
\text { al. (2014) }\end{array}$ & 5 & None & Not assessed & $\begin{array}{l}\text { * telephone advice lines provided } \\
\text { support with pain } \\
\text { management, managing symptoms, } \\
\text { and medication usages } \\
\text { * digital pens improved } \\
\text { communication with caregivers and } \\
\text { quality of care } \\
\text { * some evidence that DHIs } \\
\text { decreased hospitalisations, } \\
\text { emergency care visits, bed days, } \\
\text { and reduced costs for veteran } \\
\text { patients \& their families } \\
\text { * mobile-phone based technology } \\
\text { useful for detecting symptoms } \\
\text { earlier } \\
\text { * increased time for direct care } \\
\text { * high level of user satisfaction }\end{array}$ & $\begin{array}{l}\text { Overall, there was heterogeneity in } \\
\text { the types of interventions and } \\
\text { outcomes assessed. Some studies } \\
\text { reported some improvement on } \\
\text { quality of care, documentation } \\
\text { effort, cost, and communication. } \\
\text { Overall inadequate evidence on } \\
\text { effectiveness. Robust clinical trials } \\
\text { recommended. As quality } \\
\text { assessment was not undertaken, } \\
\text { the strength of evidence reported is } \\
\text { not known. }\end{array}$ \\
\hline $\begin{array}{l}\text { Ngwenya } \\
\text { and Mills } \\
(2014)\end{array}$ & 4 & None & Not assessed & $\begin{array}{l}\text { * blogging can be therapeutic and } \\
\text { enable people to self-reflect } \\
\text { * enables people to openly express } \\
\text { feeling and opinions } \\
\text { * creates sense of identity and } \\
\text { connection online } \\
\text { * theme of empowerment } \\
\text { identified } \\
\text { * communication: new way for } \\
\text { patients and hospice staff to }\end{array}$ & $\begin{array}{l}\text { Weblogs were found to be helpful } \\
\text { and therapeutic to PC bloggers, } \\
\text { providing social support which may } \\
\text { help improve well-being. There was } \\
\text { a lack of rigorous evidence } \\
\text { demonstrating the advantages of } \\
\text { weblogs in palliative care. More } \\
\text { research is needed to assess the } \\
\text { benefits and effectiveness. Quality } \\
\text { of evidence was not assessed, but }\end{array}$ \\
\hline
\end{tabular}




\begin{tabular}{|c|c|c|c|c|c|}
\hline & & & & $\begin{array}{l}\text { communicate } \\
* \text { blogs are a low-cost intervention }\end{array}$ & $\begin{array}{l}\text { given the small number of small- } \\
\text { scale studies, overall strength of } \\
\text { evidence is likely to be low. }\end{array}$ \\
\hline $\begin{array}{l}\text { Allsop et al. } \\
\text { (2015) }\end{array}$ & 2 & None & Not assessed & $\begin{array}{l}\text { * majority of studies were non- } \\
\text { specified non-randomised } \\
\text { * no consistent measurement tools } \\
\text { used across studies. } \\
\text { * ICT helps with gathering clinical } \\
\text { information before consultation } \\
\text { * provides flexibility of symptom } \\
\text { reporting } \\
\text { * } 2 \text { types of communication } \\
\text { identified: patient to health } \\
\text { professional with no feedback and } \\
\text { patient to health professional with } \\
\text { feedback after health professional } \\
\text { reviews information. } \\
\text { * communication: systems for } \\
\text { facilitating communication did not } \\
\text { increase communication between } \\
\text { patient and health professionals }\end{array}$ & $\begin{array}{l}\text { ICT systems for symptom reporting } \\
\text { are emerging in the palliative care } \\
\text { context. Most are at an early stage } \\
\text { of development. There is a need to } \\
\text { increase the quality and scale of } \\
\text { development work and explore how } \\
\text { to effectively use system feedback } \\
\text { with patients. As quality assessment } \\
\text { was not undertaken, the strength of } \\
\text { evidence reported is not known. }\end{array}$ \\
\hline $\begin{array}{l}\text { Chi and } \\
\text { Demiris } \\
(2015)\end{array}$ & 3 & $\begin{array}{l}\text { Oxford Centre } \\
\text { for Evidence- } \\
\text { based Medicine } \\
\text { framework }\end{array}$ & $\begin{array}{l}\text { Medium to high } \\
\text { quality }\end{array}$ & $\begin{array}{l}\text { * improved communication } \\
\text { * improved satisfaction levels } \\
\text { * improved anxiety levels and QOL } \\
\text { * improved problem-solving } \\
\text { abilities } \\
\text { * } 1 \text { study showed no differences in } \\
\text { parental QOL between control } \\
\text { group and telehealth group }\end{array}$ & $\begin{array}{l}\text { Telehealth provides positive effects } \\
\text { for caregivers of people with } \\
\text { chronic diseases who are receiving } \\
\text { palliative care, including improved } \\
\text { satisfaction, quality of life and } \\
\text { psychological wellbeing. Findings } \\
\text { are based on a sub-sample of } \\
\text { studies reported in the full paper. } \\
\text { Overall evidence was assessed as } \\
\text { medium to high quality. }\end{array}$ \\
\hline
\end{tabular}




\begin{tabular}{|c|c|c|c|c|c|}
\hline $\begin{array}{l}\text { Ostherr et } \\
\text { al. (2016) }\end{array}$ & 5 & $\begin{array}{l}\text { Cochrane risk of } \\
\text { bias tool }\end{array}$ & $\begin{array}{l}\text { Studies were } \\
\text { judged to be at } \\
\text { medium to high } \\
\text { risk of bias, } \\
\text { mainly due to } \\
\text { non blinding of } \\
\text { participants and } \\
\text { outcomes, and } \\
\text { small sample } \\
\text { sizes. }\end{array}$ & $\begin{array}{l}\text { * ICTs were most commonly used to } \\
\text { provide information or education, } \\
\text { serve as decision aids, promote } \\
\text { advance care planning (ACP), and } \\
\text { relieve physical symptom distress } \\
\text { *Over half of all included studies } \\
\text { used video, and the evidence base } \\
\text { for the use of video in EOL } \\
\text { communication was judged as } \\
\text { strong. } \\
\text { *Video was an effective decision } \\
\text { support tool for ACP. } \\
\text { *Video were useful for education } \\
\text { and communication purposes. }\end{array}$ & $\begin{array}{l}\text { The evidence base for the use of } \\
\text { video in end-of-life care } \\
\text { communication was judged as } \\
\text { strong, though overall evidence was } \\
\text { judged to be at medium to high risk } \\
\text { of bias. Several studies } \\
\text { demonstrated the efficacy of video } \\
\text { as a decision support tool in ACP. } \\
\text { Few studies involving mobile and } \\
\text { connected platforms. The value of } \\
\text { video in helping patients } \\
\text { clarify their treatment preferences } \\
\text { should motivate more } \\
\text { providers to experiment with this } \\
\text { medium using mobile devices. } \\
\text { Further research based on mobile } \\
\text { technologies is needed. }\end{array}$ \\
\hline
\end{tabular}




\begin{tabular}{|c|c|c|c|c|c|}
\hline $\begin{array}{l}\text { Zheng et al. } \\
\text { (2016) }\end{array}$ & 3 & $\begin{array}{l}\text { Cochrane risk of } \\
\text { bias tool }\end{array}$ & $\begin{array}{l}\text { Of the nine } \\
\text { studies, the } \\
\text { majority ( } 77.8 \%) \\
\text { were judged as } \\
\text { moderate } \\
\text { quality. Only } \\
\text { two of the nine } \\
\text { studies reported } \\
\text { a } \\
\text { randomized } \\
\text { process of } \\
\text { participant } \\
\text { recruitment and } \\
\text { allocation, and } \\
\text { none reported } \\
\text { using a process } \\
\text { for blinding } \\
\text { participants. }\end{array}$ & $\begin{array}{l}\text { * } 5 \text { studies on QOL did not show } \\
\text { any significant differences between } \\
\text { the intervention and control groups } \\
\text { * } 4 \text { studies reported telehealth } \\
\text { interventions are feasible } \\
\text { * } 5 \text { studies found caregivers' to be } \\
\text { satisfied with the telehealth } \\
\text { intervention } \\
\text { * Decreased physical QOL in one } \\
\text { study } \\
\text { * } 2 \text { studies show significant } \\
\text { decrease in anxiety levels after the } \\
\text { intervention, but } 1 \text { showed no } \\
\text { significant improvement } \\
* 1 \text { study reported reduced burden } \\
\text { on caregivers } \\
* 1 \text { study did not show any } \\
\text { significant differences on burden } \\
\text { levels } \\
* 1 \text { study found improved family } \\
\text { functioning } \\
* 1 \text { study found online symptom } \\
\text { reporting reduced negative mood } \\
* 1 \text { study found decreased } \\
\text { depression and perceived stress } \\
\text { over time }\end{array}$ & $\begin{array}{l}\text { There is evidence of overall } \\
\text { satisfaction in caregivers who use a } \\
\text { telehealth intervention, but } \\
\text { outcomes reported were often not } \\
\text { substantial. Overall study quality } \\
\text { was judged moderate, but } \\
\text { methodological flaws and small } \\
\text { sample sizes negatively affected } \\
\text { study quality. More rigorous } \\
\text { research to test and evaluate such } \\
\text { palliative interventions is needed. }\end{array}$ \\
\hline
\end{tabular}




\begin{tabular}{|c|c|c|c|c|c|}
\hline $\begin{array}{l}\text { Head et al. } \\
(2017)\end{array}$ & 7 & $\begin{array}{l}\text { Cochrane risk of } \\
\text { bias tool }\end{array}$ & $\begin{array}{l}\text { Of the } 6 \text { studies } \\
\text { reporting } \\
\text { quantitative } \\
\text { outcomes, } 3 \\
\text { studies were } \\
\text { moderate } \\
\text { quality and } 3 \\
\text { were low } \\
\text { quality. } \\
\text { Of the six } \\
\text { qualitative } \\
\text { studies, quality } \\
\text { scores ranged } \\
\text { from } 2 \text { to } 5 \text { out } \\
\text { of a possible } \\
\text { score of } 11 . \\
\text { Information was } \\
\text { lacking on } \\
\text { several } \\
\text { dimensions } \\
\text { which may have } \\
\text { contributed to } \\
\text { the low scores. }\end{array}$ & $\begin{array}{l}\text { * } 4 \text { studies reported positive } \\
\text { patient satisfaction with the } \\
\text { eHealth intervention } \\
\text { * } 2 \text { studies measured QOL, } 1 \\
\text { showed no significant difference } \\
\text { while other showed positive effects } \\
\text { * } 3 \text { studies reported improvement } \\
\text { symptoms after intervention, } 1 \\
\text { found no effect. } \\
\text { * } 2 \text { studies reported decreased } \\
\text { anxiety and depression } \\
\text { *2 studies found decreased hospital } \\
\text { costs due to eHealth intervention }\end{array}$ & $\begin{array}{l}\text { All studies, except one, reported } \\
\text { positive results for eHealth } \\
\text { interventions. But overall evidence } \\
\text { for positive patient outcomes in } \\
\text { palliative telehealth interventions } \\
\text { was weak. There was wide } \\
\text { variability across the studies in } \\
\text { terms of patient population, } \\
\text { outcomes measured, methodology, } \\
\text { and technology used. Lack of } \\
\text { standardised outcomes alongside } \\
\text { recruitment challenges and attrition } \\
\text { made evaluation difficult. }\end{array}$ \\
\hline
\end{tabular}




\begin{tabular}{|c|c|c|c|c|c|}
\hline $\begin{array}{l}\text { Taroco et al. } \\
\text { (2017) }\end{array}$ & 6 & None & Not assessed & $\begin{array}{l}\text { * majority of educational initiatives } \\
\text { aimed at nurses and HPs } \\
\text { * half of overall courses focused on } \\
\text { PC as a general topic } \\
\text { * courses lasted between 2-6 } \\
\text { months on average } \\
\text { * most courses were mixed in their } \\
\text { delivery approach } \\
\text { * half of the courses used pretest } \\
\text { and post-tests and the other half } \\
\text { used only post-tests } \\
\text { * online mixed teaching methods } \\
\text { enable practical and theoretical } \\
\text { activities in a cost-effective manner } \\
\text { which helps healthcare settings } \\
\text { with limited resources } \\
\text { *Evaluation of distance learning } \\
\text { outcomes was not undertaken. }\end{array}$ & $\begin{array}{l}\text { Evaluation outcomes were not } \\
\text { reported. Limited research } \\
\text { exploring the construction process } \\
\text { of courses and how they can be } \\
\text { applied to countries with limited } \\
\text { resources was identified. Quality } \\
\text { assessment was not undertaken. }\end{array}$ \\
\hline $\begin{array}{l}\text { Allsop et al. } \\
\text { (2018) }\end{array}$ & 6 & None & Not assessed & $\begin{array}{l}\text { * Health workers in remote areas } \\
\text { were finding innovative ways to use } \\
\text { mHealth technologies. } \\
\text { * mHealth technologies used to } \\
\text { improve appointment adherence in } \\
\text { resource limited areas and facilitate } \\
\text { communication with patients and } \\
\text { families } \\
\text { * mHealth used for information and } \\
\text { educational purposes. } \\
\text { *Short term lectures and } \\
\text { informational text messages can } \\
\text { help empower physicians } \\
\text { *Patients preference mobile phone } \\
\text { over travelling long distances }\end{array}$ & $\begin{array}{l}\text { Existing mHealth interventions in } \\
\text { sub-Saharan Africa are limited in } \\
\text { number and are being used at the } \\
\text { palliative treatment, guidance and } \\
\text { coordination stage of care } \\
\text { provision. A lack of information } \\
\text { relating to mHealth infrastructure } \\
\text { requirements, technology and } \\
\text { platforms used, and costs related to } \\
\text { delivering the intervention was } \\
\text { noted. As quality assessment was } \\
\text { not undertaken, the strength of } \\
\text { evidence reported is not known. }\end{array}$ \\
\hline
\end{tabular}




\begin{tabular}{|c|c|c|c|c|c|}
\hline $\begin{array}{l}\text { Bush et al } \\
\text { (2018) }\end{array}$ & 5 & None & Not assessed & $\begin{array}{l}5 \text { major areas in which the EHR is } \\
\text { used to support palliative care were } \\
\text { identified: } \\
\text { *identifying individuals who could } \\
\text { benefit from palliative care } \\
\text { *enhancement of the EHR to } \\
\text { improve palliative care } \\
\text { * advance care planning (ACP) } \\
\text { documentation; } \\
\text { * patient-reported outcomes such } \\
\text { as rapid, real-time pain feedback } \\
\text { *enhancing interdisciplinary } \\
\text { communication. }\end{array}$ & $\begin{array}{l}\text { Studies focused on clinical decision } \\
\text { systems to: identify individuals who } \\
\text { could benefit from PC; facilitate } \\
\text { electronic advanced care planning } \\
\text { (ACP) documentation; improve } \\
\text { patient-reported outcome } \\
\text { measures (PROMs); to augment } \\
\text { EHR PC data capture capabilities; } \\
\text { and to enhance interdisciplinary } \\
\text { communication and care. The use } \\
\text { of EHRs and clinical decision system } \\
\text { are underutilised despite some } \\
\text { evidence for their usefulness. } \\
\text { Quality assessment was not } \\
\text { undertaken. }\end{array}$ \\
\hline $\begin{array}{l}\text { Smith et al } \\
\text { (2018) }\end{array}$ & 9 & $\begin{array}{l}\text { Kirkpatrick's } \\
\text { level of } \\
\text { evaluation was } \\
\text { used to } \\
\text { differentiate } \\
\text { the level } \\
\text { of evaluation } \\
\text { assessment } \\
\text { completed. }\end{array}$ & $\begin{array}{l}\text { Lack of } \\
\text { standardization, } \\
\text { poor evaluation } \\
\text { methods, and } \\
\text { limited exposure } \\
\text { to the entire } \\
\text { interprofessional } \\
\text { team made it } \\
\text { difficult to } \\
\text { identify and } \\
\text { disseminate } \\
\text { validated best } \\
\text { practices. }\end{array}$ & $\begin{array}{l}\text { *Simulation-based learning is being } \\
\text { used to teach palliative and end of } \\
\text { life care. } \\
\text { *High fidelity simulators are the } \\
\text { most common technology used. } \\
\text { * Most simulation-based learning } \\
\text { experiences are supported by video } \\
\text { review. } \\
{ }^{*} \text { The wide variety and } \\
\text { heterogeneity of simulation-based } \\
\text { learning experiences made it } \\
\text { difficult to draw conclusion on } \\
\text { effectiveness. }\end{array}$ & $\begin{array}{l}\text { Simulation-based learning } \\
\text { experience are being used to teach } \\
\text { palliative and end-of-life } \\
\text { communication skills to nursing } \\
\text { students and clinicians. Lack of } \\
\text { standardization, poor evaluation } \\
\text { methods, and limited exposure to } \\
\text { the entire interprofessional team } \\
\text { makes it difficult to identify and } \\
\text { disseminate validated best } \\
\text { practices. Further research is } \\
\text { needed employing rigorous } \\
\text { evaluation methods and measures } \\
\text { that link the SBLE to the training } \\
\text { objectives and desired clinician } \\
\text { practice behaviours and patient } \\
\text { outcomes. As quality assessment } \\
\text { was not undertaken, the strength of } \\
\text { evidence reported is not known. }\end{array}$ \\
\hline
\end{tabular}




\begin{tabular}{|c|c|c|c|c|c|}
\hline $\begin{array}{l}\text { Huber et al } \\
(2018)\end{array}$ & 6 & None & Not assessed & $\begin{array}{l}\text { *The most common EHR } \\
\text { interventions described were } \\
\text { documentation templates, followed } \\
\text { by prompts and electronic order } \\
\text { sets. } \\
\text { *Documentation templates can } \\
\text { reduce variability in documentation } \\
\text { and gather information associated } \\
\text { with high quality ACP } \\
\text { *All studies reporting efficacy ( } n=7 \text { ) } \\
\text { reported an improvement in one or } \\
\text { more ACP outcomes. }\end{array}$ & $\begin{array}{l}\text { EHR interventions, such as } \\
\text { documentation templates, } \\
\text { order sets, and prompts, may } \\
\text { improve the incidence and quality } \\
\text { of ACP and may improve ACP } \\
\text { completion and availability at the } \\
\text { point of care. As quality } \\
\text { assessment was not undertaken, } \\
\text { the strength of evidence reported is } \\
\text { not known. }\end{array}$ \\
\hline $\begin{array}{l}\text { Hancock et } \\
\text { al (2019) }\end{array}$ & 9 & $\begin{array}{l}\text { Critical } \\
\text { appraisal based } \\
\text { on criteria } \\
\text { adapted from } \\
\text { Wallace (2004). }\end{array}$ & $\begin{array}{l}\text { Eight of the } 19 \\
\text { papers met all } \\
\text { the nine criteria } \\
\text { completely or to } \\
\text { some extent. } \\
11 \text { papers did } \\
\text { not meet the } \\
\text { nine criteria } \\
\text { because of } \\
\text { insufficient } \\
\text { sample sizes or } \\
\text { insufficient } \\
\text { description of } \\
\text { data collection } \\
\text { methods. }\end{array}$ & $\begin{array}{l}\text { *Telehealth was used to support } \\
\text { patients and carers, monitor } \\
\text { symptoms and provide education. } \\
\text { *The number of home } \\
\text { telemonitoring initiatives for } \\
\text { patients had increased since } 2010 \text {. } \\
\text { *Many studies were small scale, } \\
\text { descriptive and provided little } \\
\text { evidence of evaluation of the } \\
\text { service. } \\
\text { *Seven included studies made } \\
\text { specific reference to reduction } \\
\text { in access to emergency or acute } \\
\text { care services. }\end{array}$ & $\begin{array}{l}\text { Telehealth was used to support } \\
\text { patients and carers, electronic } \\
\text { record keeping and professional } \\
\text { education. However, many studies } \\
\text { were small scale, descriptive and } \\
\text { provided little evidence of } \\
\text { evaluation of the service. There } \\
\text { remains a lack of evaluation and } \\
\text { robust study design meaning } \\
\text { conclusions regarding the clinical } \\
\text { application of telehealth in } \\
\text { palliative care cannot be drawn. } \\
\text { There is insufficient evidence to } \\
\text { appreciate any benefit of telehealth } \\
\text { on access to emergency care. }\end{array}$ \\
\hline
\end{tabular}




\begin{tabular}{|c|c|c|c|c|c|}
\hline $\begin{array}{l}\text { Jess et al } \\
\text { (2019) }\end{array}$ & 8 & $\begin{array}{l}\text { Quality } \\
\text { assessment was } \\
\text { based on a tool } \\
\text { developed by } \\
\text { Hawker et al. } \\
\text { (2002). Each } \\
\text { study could } \\
\text { receive } \\
\text { between } 10 \text { and } \\
40 \text { points. }\end{array}$ & $\begin{array}{l}\text { Studies scored } \\
\text { between } 20 \text { and } \\
36 \text { points with } \\
\text { an average score } \\
\text { of } 27.4 \text { points } \\
\text { (possible range } \\
\text { 10-40). } \\
\text { Studies scored } \\
\text { lowest in ethics } \\
\text { and bias, as } \\
\text { these criteria } \\
\text { were often } \\
\text { inadequately } \\
\text { reported. }\end{array}$ & $\begin{array}{l}\text { *Video-consultations enabled } \\
\text { patient and/or relative to connect } \\
\text { with one or more health } \\
\text { professionals in different locations } \\
\text { enabling wider participation, } \\
\text { reductions in travel burden, and a } \\
\text { reduction in emergency admissions. } \\
\text { *Video consultations enabled } \\
\text { communication as several } \\
\text { participants could be visually } \\
\text { present and communicate with } \\
\text { each other and resolve issues in one } \\
\text { consultation. Enabled shared } \\
\text { decision-making and facilitated } \\
\text { carer involvement. } \\
\text { * Most patients, relatives and } \\
\text { health care professionals were } \\
\text { positive towards the technology } \\
\text { which provided a feeling of security. } \\
\text { *User friendliness was a facilitator. } \\
\text { *Technical challenges were a } \\
\text { barrier to uptake. } \\
\text { *Some patients were reluctant to } \\
\text { give health care professionals visual } \\
\text { access to their home. } \\
\text { *3 out of } 4 \text { studies found that video } \\
\text { consultations had economic } \\
\text { advantages for providers or } \\
\text { patients. }\end{array}$ & $\begin{array}{l}\text { Video consultations enable clinical } \\
\text { assessment and support and } \\
\text { effective verbal and non-verbal } \\
\text { communication at a distance. } \\
\text { However, evidence beyond } \\
\text { specialized palliative care and } \\
\text { patients with cancer is limited. } \\
\text { Some studies report cost-savings } \\
\text { and most users were positive } \\
\text { towards the technology. Technical } \\
\text { challenges could be a barrier and } \\
\text { there are implications for patients' } \\
\text { privacy and security. Future } \\
\text { research should focus on how and } \\
\text { when video consultations might } \\
\text { replace in-person specialized } \\
\text { palliative care and video } \\
\text { consultations in general palliative } \\
\text { care, in low- and middle-income } \\
\text { countries; and involving patients } \\
\text { with a non-cancer diagnosis. }\end{array}$ \\
\hline
\end{tabular}




\begin{tabular}{|c|c|c|c|c|c|}
\hline $\begin{array}{l}\text { Leniz et al } \\
(2019)\end{array}$ & 8 & $\begin{array}{l}\text { Standard } \\
\text { Quality } \\
\text { Assessment } \\
\text { Criteria (Kmet } \\
\text { et al 2004) for } \\
\text { evaluation of } \\
\text { primary } \\
\text { research papers } \\
\text { from different } \\
\text { fields. }\end{array}$ & $\begin{array}{l}\text { Mean quality } \\
\text { appraisal score } \\
\text { for quantitative } \\
\text { studies was } 85 \% \text {. } \\
\text { The most } \\
\text { common source } \\
\text { of poor quality } \\
\text { for quantitative } \\
\text { studies was the } \\
\text { lack of an } \\
\text { evident and } \\
\text { appropriate } \\
\text { study design and } \\
\text { a poorly defined } \\
\text { comparison } \\
\text { group. } \\
\text { Mean quality } \\
\text { appraisal score } \\
\text { for qualitative } \\
\text { studies was } 83 \% \text {. } \\
\text { The most } \\
\text { common source } \\
\text { of poor quality } \\
\text { for qualitative } \\
\text { studies was a } \\
\text { lack of reflexivity } \\
\text { of the account } \\
\text { and description } \\
\text { of the } \\
\text { theoretical } \\
\text { framework. }\end{array}$ & $\begin{array}{l}\text { *Place of death: } 4 \text { studies reported } \\
\text { the proportion of people who died } \\
\text { in their preferred place ( } 55 \% \text { to } \\
79 \% \text { - higher than the average for } \\
\text { the population. } \\
\text { *Two of the highest quality studies } \\
\text { found that EPaCCS use was } \\
\text { associated with lower odds of } \\
\text { hospital death, hospital admission } \\
\text { and emergency department } \\
\text { attendance } \\
\text { *Qualitative evidence found that } \\
\text { EPaCCS are generally acceptable for } \\
\text { patients and healthcare } \\
\text { professionals. However, in-hours } \\
\text { staff perceived EPaCCS as a } \\
\text { potential burden due to an } \\
\text { increased workload without } \\
\text { perceivable benefit to them, while } \\
\text { out-of-hours staff perceived EPaCCS } \\
\text { to be more useful. Only two studies } \\
\text { sought patient perspectives. }\end{array}$ & $\begin{array}{l}\text { Much of the current scientific } \\
\text { literature on EPaCCS comprises } \\
\text { expert opinion. There is an absence } \\
\text { of experimental studies evaluating } \\
\text { the impact of EPaCCS on end-of-life } \\
\text { outcomes. Further rigorous } \\
\text { evaluations of EPaCCS, including } \\
\text { economic impacts, need to be } \\
\text { prioritised. }\end{array}$ \\
\hline
\end{tabular}




\begin{tabular}{|c|c|c|c|c|c|}
\hline $\begin{array}{l}\text { Lemon et al } \\
\text { (2019) }\end{array}$ & 8 & $\begin{array}{l}\text { Cochrane risk of } \\
\text { bias tool }\end{array}$ & $\begin{array}{l}\text { Most studies } \\
\text { had an unclear } \\
\text { or high risk of } \\
\text { bias. }\end{array}$ & $\begin{array}{l}\text { *7 studies showed that EMR-based } \\
\text { reminders, AD templates, and } \\
\text { decision aids can improve AD } \\
\text { documentation rates. } \\
\text { *3 demonstrated that EMR search } \\
\text { functions, decision aids, and } \\
\text { automatic identification software } \\
\text { can help identify patients who have } \\
\text { or need Ads. } \\
\text { *5 showed EMRs can create } \\
\text { documentation challenges, } \\
\text { including locating ADs, and making } \\
\text { some patients more likely than } \\
\text { others to have an AD. }\end{array}$ & $\begin{array}{l}\text { Limited evidence suggests } \\
\text { electronic medical records could be } \\
\text { used to help address advance } \\
\text { directive documentation challenges } \\
\text { but may also create additional } \\
\text { problems. Stronger evidence is } \\
\text { needed to determine how } \\
\text { electronic medical records more } \\
\text { conclusively may assist in } \\
\text { population approaches to } \\
\text { improving advance directive } \\
\text { documentation. }\end{array}$ \\
\hline
\end{tabular}

